NASA/TM-2002-211372

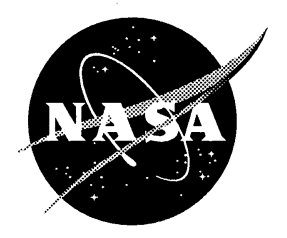

\title{
Upper Temperature Limit of Environmental Barrier Coatings Based on Mullite and BSAS
}

K.N. Lee

Cleveland State University, Cleveland, Ohio

D.S. Fox and J.I. Eldridge

Glenn Research Center, Cleveland, Ohio

D. Zhu

Ohio Aerospace Institute, Brook Park, Ohio

R.C. Robinson

QSS Group, Inc., Cleveland, Ohio

N.P. Bansal and R.A. Miller

Glenn Research Center, Cleveland, Ohio 
Since its founding, NASA has been dedicated to the advancement of aeronautics and space science. The NASA Scientific and Technical Information (STI) Program Office plays a key part in helping NASA maintain this important role.

The NASA STI Program Office is operated by Langley Research Center, the Lead Center for NASA's scientific and technical information. The NASA STI Program Office provides access to the NASA STI Database, the largest collection of aeronautical and space science STI in the world. The Program Office is also NASA's institutional mechanism for disseminating the results of its research and development activities. These results are published by NASA in the NASA STI Report Series, which includes the following report types:

- TECHNICAL PUBLICATION. Reports of completed research or a major significant phase of research that present the results of NASA programs and include extensive data or theoretical analysis. Includes compilations of significant scientific and technical data and information deemed to be of continuing reference value. NASA's counterpart of peerreviewed formal professional papers but has less stringent limitations on manuscript length and extent of graphic presentations.

- TECHNICAL MEMORANDUM. Scientific and technical findings that are preliminary or of specialized interest, e.g., quick release reports, working papers, and bibliographies that contain minimal annotation. Does not contain extensive analysis.

- CONTRACTOR REPORT. Scientific and technical findings by NASA-sponsored contractors and grantees.
- CONFERENCE PUBLICATION. Collected papers from scientific and technical conferences, symposia, seminars, or other meetings sponsored or cosponsored by NASA.

- SPECIAL PUBLICATION. Scientific, technical, or historical information from NASA programs, projects, and missions, often concerned with subjects having substantial public interest.

- TECHNICAL TRANSLATION. Englishlanguage translations of foreign scientific and technical material pertinent to NASA's mission.

Specialized services that complement the STI Program Office's diverse offerings include creating custom thesauri, building customized data bases, organizing and publishing research results ... even providing videos.

For more information about the NASA STI Program Office, see the following:

- Access the NASA STI Program Home Page at http://www.sti.nasa.gov

- E-mail your question via the Internet to help@sti.nasa.gov

- Fax your question to the NASA Access Help Desk at 301-621-0134

- Telephone the NASA Access Help Desk at 301-621-0390

- Write to:

NASA Access Help Desk

NASA Center for AeroSpace Information 7121 Standard Drive

Hanover, MD 21076 
NASA/TM-2002-211372

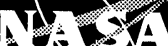

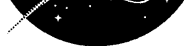

\section{Upper Temperature Limit of Environmental Barrier Coatings Based on Mullite and BSAS}

K.N. Lee

Cleveland State University, Cleveland, Ohio

D.S. Fox and J.I. Eldridge

Glenn Research Center, Cleveland, Ohio

D. Zhu

Ohio Aerospace Institute, Brook Park, Ohio

R.C. Robinson

QSS Group, Inc., Cleveland, Ohio

N.P. Bansal and R.A. Miller

Glenn Research Center, Cleveland, Ohio

National Aeronautics and

Space Administration

Glenn Research Center 


\section{Acknowledgments}

We are grateful to J. Smith of QSS Group, Inc. for microprobe analysis, R. Garlick of NASA for XRD, G.W. Leissler of QSS Group, Inc. for the preparation of plasma spray coatings, S.L. Leissler of QSS Group, Inc. for the metallographic preparation of tested EBCs, and L. Bunyak of Akima Corporation for HPBR operation/support. This work was supported by the NASA Ultra Efficient Engine Technology (UEET) Program.

\section{Available from}

NASA Center for Aerospace Information 7121 Standard Drive Hanover, MD 21076
National Technical Information Service 5285 Port Royal Road Springfield, VA 22100

Available electronically at http://gltrs.grc.nasa.gov/GLTRS 


\title{
UPPER TEMPERATURE LIMIT OF ENVIRONMENTAL BARRIER COATINGS BASED ON MULLITE AND BSAS
}

\author{
Kang N. Lee \\ Cleveland State University \\ Cleveland, Ohio 44115 \\ Dennis S. Fox, Jeffrey I. Eldridge, Narottam P. Bansal, and Robert A. Miller \\ National Aeronautics and Space Administration \\ Glenn Research Center \\ Cleveland, Ohio 44135 \\ Dongming Zhu \\ Ohio Aerospace Institute \\ Brook Park, Ohio 44142 \\ Raymond C. Robinson \\ QSS Group, Inc. \\ Cleveland, Ohio 44135
}

\begin{abstract}
Current state-of-the-art environmental barrier coatings (EBCs) for Si-based ceramics consist of three layers: a silicon bond coat, an intermediate mullite $\left(3 \mathrm{Al}_{2} \mathrm{O}_{3}-2 \mathrm{SiO}_{2}\right)$ or mullite $+\mathrm{BSAS}$ (1-xBaO-xSrO- $\left.\mathrm{Al}_{2} \mathrm{O}_{3}-2 \mathrm{SiO}_{2}\right)$ layer, and a BSAS top coat. Areas of concern for long-term durability are environmental durability, chemical compatibility, silica volatility, phase stability, and thermal conductivity. Variants of this family of EBCs were applied to monolithic SiC and melt infiltrated $\mathrm{SiC} / \mathrm{SiC}$ composites. Reaction between BSAS and silica results in low melting $\left(\sim 1300^{\circ} \mathrm{C}\right)$ glasses at $\mathrm{T}>1400^{\circ} \mathrm{C}$, which can cause the spallation of the EBC. At temperatures greater than $1400^{\circ} \mathrm{C}$, the BSAS top coat also degrades by formation of a porous structure, and it suffers significant recession via silica volatilization in water vapor-containing atmospheres. All of these degradation mechanisms can be EBC life-limiting factors. BSAS undergoes a very sluggish phase transformation (hexagonal celsian to monoclinic celsian), the implications of which are not fully understood at this point. There was evidence of rapid sintering at temperatures as low as $1300^{\circ} \mathrm{C}$, as inferred from the sharp increase in thermal conductivity.
\end{abstract}

\section{INTRODUCTION}

A major limitation in the performance (efficiency and emission) of current gas turbines is the temperature capability (strength and durability) of the metallic structural components (blades, nozzles, and combustor liners) in the engine hot section. It is generally agreed that the temperature capability of metals has reached their limit. Ceramic thermal barrier coatings are used to insulate metallic components, thereby allowing higher gas temperatures, but the metallic component remains a weak link because the designer must allow for the possibility of coating loss from spallation or erosion. Ceramic components, with an appropriate coating, exhibit superior high-temperature strength and durability, signifying their potential to revolutionize the gas turbine engine technology. Silicon-based ceramics, such as SiC fiber-reinforced SiC ceramic 
matrix composites ( $\mathrm{SiC} / \mathrm{SiC} \mathrm{CMCs})$ and monolithic silicon nitride $\left(\mathrm{Si}_{3} \mathrm{~N}_{4}\right)$, are prime candidates for such applications. Silicon-based ceramics, however, suffer from rapid surface recession in combustion environments. This is due to the volatilization of the silica scale via reaction with water vapor (1-4), a major product of combustion. Therefore, application of silicon-based ceramic components in the hot section of advanced gas turbine engines requires development of a reliable method to protect the ceramic from environmental attack. An external environmental barrier coating (EBC) is considered a logical approach to achieve protection and long-term stability.

The first generation EBC consisted of two layers, a mullite $\left(3 \mathrm{Al}_{2} \mathrm{O}_{3}-2 \mathrm{SiO}_{2}\right)$ bond coat and a yttria-stabilized zirconia ( $\mathrm{YSZ}, \mathrm{ZrO}_{2}-8 \mathrm{wt} . \% \mathrm{Y}_{2} \mathrm{O}_{3}$ ) top coat (5). Mullite provides bonding, while YSZ provides protection from water vapor. Excellent CTE match and chemical compatibility with Si-based ceramics make mullite an excellent bond coat candidate. However, the relatively high silica activity of mullite (0.3-0.4), and the resulting selective volatilization of silica, cause its rapid recession in water vapor (5). YSZ has been successfully used as a thermal barrier coating (TBC) for metallic components in gas turbine engines, indicating its durability in water vapor. The first generation $\mathrm{EBC}$ could provide protection from water vapor for a few hundred hours at $1300{ }^{\circ} \mathrm{C}(5)$. During longer exposures, however, water vapor penetrated through cracks in the mullite and attacked the Si-based substrate, leading to coating delamination.

Second generation EBCs, with substantially improved performance compared with the first generation EBC, were developed as a part of the NASA High Speed Research-Enabling Propulsion Materials (HSR-EPM) Program in joint research by NASA, GE, and Pratt \& Whitney $(6,7)$. The new EBCs consist of three layers: a silicon bond coat, a mullite or a mullite + BSAS (1-xBaO-xSrO- $\mathrm{Al}_{2} \mathrm{O}_{3}-2 \mathrm{SiO}_{2}$ ) intermediate coat, and a BSAS top coat. The mullite, mullite + BSAS, and BSAS layers are applied by a modified plasma spray process, developed at the NASA Glenn Research Center (8). The EPM EBCs have been applied to SiC/SiC CMC combustor liners used in three Solar Turbine (San Diego, CA) Centaur 50s gas turbine engines (7). The combined operation of the three engines has resulted in the accumulation of over 24,000 hours without failure $\left(\sim 1,250^{\circ} \mathrm{C}\right.$ maximum combustor liner temperature), with the engine used by Texaco in Bakersfield, CA, accumulating about 14,000 hours. The higher operating temperature resulted in emissions consistently below 15 ppmv NOx and below 10 ppmv CO throughout, roughly reducing the NOx and CO loads on the environment by factors of about 2 and 5 , respectively.

Research is underway to further advance EBCs at the NASA Glenn Research Center under the support of the Ultra Efficient Engine Technology (UEET) Program. The goal is to develop EBCs that can withstand a $1482{ }^{\circ} \mathrm{C}\left(2700^{\circ} \mathrm{F}\right)$ surface temperature over thousands of hours while sustaining at least a $167{ }^{\circ} \mathrm{C}\left(300^{\circ} \mathrm{F}\right)$ temperature gradient. Thorough understanding of environmental, chemical, physical, and mechanical properties of current state-of-the-art EBCs will provide the foundation upon which future EBCs will be based. A task was therefore undertaken to characterize the EPM EBCs, with the main focus on determining an upper temperature limit. Key areas investigated were environmental and chemical durability, phase stability, and thermal conductivity. This paper will discuss the results of that investigation and the implication on the upper temperature limit of current state-of-the-art EBCs. 


\section{EXPERIMENTAL}

EBCs were applied by atmospheric pressure plasma spraying onto sintered $\alpha$-SiC coupons $\left(\right.$ Hexoloy $^{\mathrm{TM}}$, Carborundum, Niagara Falls, NY) or melt infiltrated (MI) SiC/SiC composites (GE Power Systems Composites, Newark, Delaware) (9). The monolithic $\mathrm{SiC}$ was etched in $\mathrm{Na}_{2} \mathrm{CO}_{3}$ to create a rough surface $\left(\mathrm{R}_{\mathrm{a}}{ }^{*}=5-6 \mu \mathrm{m}\right)$ necessary for good mechanical bond with coating. The MI CMC was used as processed. Silicon powder was purchased from Atlantic Equipment Engineers (Bergenfield, NJ), mullite powder from Cerac, Inc. (Milwaukee, WI), and BSAS powder from H.C. Starck Inc. (Newton, MA). Two types of silicon bond coat were used: the silicon surface layer already present on as-processed MI with the thickness ranging from a few microns to $\sim 100 \mu \mathrm{m}$; or plasma-sprayed silicon, typically $50-75 \mu \mathrm{m}(2-3 \mathrm{mils})$ thick. The subsequent coating layers were $\sim 125-250 \mu \mathrm{m}(5-10 \mathrm{mils})$ thick each. Three variants of EBCs were examined in this study: BSAS only, $\mathrm{Si} /($ mullite+BSAS)/BSAS, and $\mathrm{Si} / \mathrm{mullite} / \mathrm{BSAS}$. Details of the coating process parameters are described elsewhere (8).

EBC-coated MI or $\mathrm{SiC}$ coupons were used for furnace thermal cycling in air or water vapor, high-pressure burner rig (HPBR) tests, Raman spectroscopy studies, and high heat flux laser thermal conductivity measurements. All EBC-coated SiC or MI coupons were annealed in air at $1300{ }^{\circ} \mathrm{C}$ for $20 \mathrm{~h}$ prior to testing to stabilize the coating phase. Thermogravimetric analysis (TGA) of hot-pressed, monolithic BSAS coupons was used to study volatilization in water vapor.

Thermal cycling was conducted at 1300 to $1500{ }^{\circ} \mathrm{C}$ in either laboratory air or $90 \% \mathrm{H}_{2} \mathrm{O}$ balance $\mathrm{O}_{2}$ (to simulate a lean combustion environment), flowing at $2.2 \mathrm{~cm} / \mathrm{s}$ at $1 \mathrm{~atm}$, using an automated thermal cycling furnace. A schematic is shown in Fig. 1. Each thermal cycle consisted of 1 or $2 \mathrm{~h}$ (high frequency cycling) or $20 \mathrm{~h}$ (low frequency cycling) at temperature, rapid cooling to room temperature, and $20 \mathrm{~min}$ at room temperature. Samples reached peak temperature within $2 \mathrm{~min}$, and cooled to room temperature within $5 \mathrm{~min}$ in each cycle. Typical sample size was $2.5 \mathrm{~cm} \times 0.6 \mathrm{~cm} \times 0.15 \mathrm{~cm}$. TGA of monolithic BSAS was conducted in $50 \% \mathrm{H}_{2} \mathrm{O}-50 \% \mathrm{O}_{2}$ flowing at $4.4 \mathrm{~cm} / \mathrm{s}$ at 1 atm total pressure. Temperatures from $1200^{\circ}$ to $1500^{\circ} \mathrm{C}$ were used. Volatilization kinetics were measured with a continuously recording Cahn 1000 microbalance (Cerritos, CA). Sample size was nominally $2.5 \mathrm{~cm}$ x $1.25 \mathrm{~cm} \times 0.15 \mathrm{~cm}$. The high-pressure burner rig is described in detail in Ref. 10. Sample size was $7.5 \mathrm{~cm} \mathrm{x} 1.25 \mathrm{~cm} \times 0.15 \mathrm{~cm}$. Coated samples were exposed to $1300{ }^{\circ} \mathrm{C}, 6 \mathrm{~atm}$ total pressure $\left(\mathrm{pH}_{2} \mathrm{O} \sim 0.6\right)$, a fuel-to-air ratio of 0.065 , and a gas velocity of $\sim 24 \mathrm{~m} / \mathrm{sec}$. Table I lists the experimental conditions for furnace and HPBR tests.

Table I Experimental conditions for furnace and HPBR tests

\begin{tabular}{|c|c|c|c|c|c|}
\hline Test Type & $\begin{array}{c}\text { Temperature } \\
\left({ }^{\circ} \mathrm{C}\right)\end{array}$ & $\begin{array}{c}\text { Cycle } \\
\text { Frequency } \\
(\mathrm{h})\end{array}$ & $\begin{array}{c}\text { Total Pressure } \\
(\mathrm{atm})\end{array}$ & $\mathrm{pH}_{2} \mathrm{O}(\mathrm{atm})$ & $\begin{array}{c}\text { Gas Velocity } \\
(\mathrm{cm} / \mathrm{sec})\end{array}$ \\
\hline Air Furnace & $1300-1500$ & 20 or isothermal & 1 & ambient air & stagnant \\
\hline $\mathrm{H}_{2} \mathrm{O}$ Furnace & $1300-1500$ & 1 or 2 & 1 & 0.9 & 2.2 \\
\hline TGA Furnace & $1200-1500$ & isothermal & 1 & 0.5 & 4.4 \\
\hline HPBR & 1300 & 7 to 8 & 6 & 0.6 & 2400 \\
\hline
\end{tabular}

*Average distance from the roughness profile to the mean line. 
Raman spectroscopy was used for an in-depth study of BSAS phase stability. Approximately 1 -mm-thick slices of EBC-coated specimens were exposed to various length heat treatments in air. After heat treatment, polished cross sections were prepared and subsequently examined by Raman microscopy. All Raman spectra were acquired with a Renishaw System 2000 Raman microscope (Renishaw, UK) equipped with a $514.5 \mathrm{~nm}$ Ar ion laser. A 100x objective was used to focus the laser down to a $1 \mu \mathrm{m}$ spot with an incident power of about $5 \mathrm{~mW}$. Spectra were acquired for $100 \mathrm{sec}$ with the laser spot positioned at the location of interest on the EBC cross section.

A high power $\mathrm{CO}_{2}$ laser was used to thermally cycle $\mathrm{EBC}$-coated specimens $(2.54 \mathrm{~cm}$ diameter $\mathrm{x} 0.15 \mathrm{~cm}$ thick) under a high thermal gradient. Each thermal cycle consisted of $1 \mathrm{~h}$ at temperature, rapid cooling to room temperature, and $5 \mathrm{~min}$ at the room temperature. A uniform laser heat flux was obtained over the $23.9 \mathrm{~mm}$ diameter aperture region of the specimen surface by using an integrating $\mathrm{ZnSe}$ lens combined with the specimen rotation. The uniformly distributed laser beam provided surface heating of the specimen. The required specimen temperatures and thermal gradients were achieved by controlling the laser heat flux and backside air-cooling. During the laser thermal cycling test, the EBC surface temperature was measured by an $8 \mu \mathrm{m}$ infrared pyrometer, and the backside CMC surface was measured by a two-color pyrometer. The EBC surface temperature was set to $1482{ }^{\circ} \mathrm{C}\left(2700{ }^{\circ} \mathrm{F}\right)$, while the EBC/MI interface temperature was controlled to approximately $1316^{\circ} \mathrm{C}\left(2400{ }^{\circ} \mathrm{F}\right)$. Details of thermal conductivity measurement are described in Ref. 11.

\section{RESULTS}

\subsection{Chemical Compatibility / Environmental Durability}

$B S A S E B C$ : In the EPM Program, BSAS was identified as a promising EBC candidate because of its close CTE match with Si-based ceramics $\left(4-5 \times 10^{-6} /{ }^{\circ} \mathrm{C}\right)$ and low silica activity $(<0.1)$. It also possesses excellent resistance to cracking in thermal cycling, presumably due to a low elastic modulus. Figure 2 shows a cross section of MI CMC and CVD Si coated with BSAS after a $100 \mathrm{~h}$ isothermal exposure at $1300{ }^{\circ} \mathrm{C}$ in air. A thick $(10-20 \mu \mathrm{m})$ interfacial reaction zone developed at the BSAS/substrate interface, and in the case of MI, large interfacial pores developed. Analysis by EDS in Fig. 2 revealed that the reaction zone contained a high level of $\mathrm{Si}$ and a significant amount of $\mathrm{Al}$ and $\mathrm{Ba}$ (the $\mathrm{Sr}$ peak overlapped with the Si peak), suggesting a reaction between thermally grown silica and BSAS.

Figure 3 is a cross section of BSAS-coated MI after $100 \mathrm{~h}(2 \mathrm{~h}$ cycles $)$ at $1300{ }^{\circ} \mathrm{C}$ in $90 \%$ $\mathrm{H}_{2} \mathrm{O}$-balance $\mathrm{O}_{2}$. As with the MI exposed in air, large interfacial pores formed (Fig. 3(a)) and a thick reaction zone developed beneath the BSAS coating (Fig. 3(b)). A silica layer is clearly seen between the reaction zone and the MI substrate in Fig. 3(b) and the reaction zone is mostly silica with some $\mathrm{Al}_{2} \mathrm{O}_{3}$ and $\mathrm{BaO}$ according to the EDS spectra, supporting the suggestion that the reaction zone is the result of reaction between silica and BSAS. BSAS-coated MI exhibited significant interfacial reaction and pore formation even at $1200^{\circ} \mathrm{C}$. In long-term exposures, the pores continue to grow and coalesce, leading to complete coating spallation. 
Si/(Mullite+BSAS)/BSAS EBC: The chemical incompatibility between BSAS and silica can be overcome if a proper chemical barrier is available. Mullite modified with the addition of BSAS (modifier BSAS) exhibits substantially improved crack resistance and durability in water vapor compared to mullite coating (described in the next section) and much improved chemical compatibility with silica, when compared to BSAS alone (6). Figure 4 is a cross section of $\mathrm{Si} /\left(\right.$ mullite+BSAS)/BSAS EBC on MI after $100 \mathrm{~h}(1 \mathrm{~h}$ cycles $)$ in $90 \% \mathrm{H}_{2} \mathrm{O}$-balance $\mathrm{O}_{2}$ at $1300^{\circ} \mathrm{C}$. Excellent durability is demonstrated, with minimal oxidation occurring. The modifier BSAS in contact with the substrate lost its bright contrast in back scattered electron image, indicating a change in its chemical composition. EDS analysis on the reacted modifier BSAS shows spectra similar to that of the BSAS/MI reaction zone (Figs. 2 and 3), indicating a BSASsilica reaction. Raman analysis shows that the reacted modifier BSAS is amorphous. After $800 \mathrm{~h}$ at $1300{ }^{\circ} \mathrm{C}$ in $90 \% \mathrm{H}_{2} \mathrm{O}$-balance $\mathrm{O}_{2}$, the $\mathrm{EBC}$ maintained excellent durability with limited oxidation, although some areas in the mullite+BSAS layer near the Si bond coat began to show the formation of glassy reaction products (Fig. 5). After $300 \mathrm{~h}$ in water vapor at $1400{ }^{\circ} \mathrm{C}$, the $\mathrm{EBC}$ still maintained excellent adherence and limited oxidation (Fig. 6). However, more areas of glassy reaction product formed in the mullite+BSAS layer, some of which penetrated through the BSAS to the EBC surface. The EDS spectra of glassy areas showed slightly higher Ba and lower Si compared with the spectra on reacted BSAS (Fig. 4), suggesting that glassy areas are the result of continued reaction between BSAS and silica.

More severe chemical reaction and $\mathrm{EBC}$ degradation occurred at temperatures greater than $1400^{\circ} \mathrm{C}$. Figure $7(\mathrm{a})$ is a cross section of (mullite+BSAS)/BSAS EBC on $\mathrm{SiC}$ (without Si bond coat) after a $20 \mathrm{~h}$ isothermal exposure in air at $1440^{\circ} \mathrm{C}$. Figure $7(\mathrm{~b})$ is the same coating after $100 \mathrm{~h}$ (1h cycles) in $90 \% \mathrm{H}_{2} \mathrm{O}$-balance $\mathrm{O}_{2}$ at $1482{ }^{\circ} \mathrm{C}$. In both cases, the EBC completely spalled. Extensive glass formation was observed on both surfaces of the spall. Cross sections revealed spallation occurred at the $\mathrm{EBC} / \mathrm{SiC}$ interface and significant chemical reactions between mullite and BSAS.

According to the $\mathrm{SiO}_{2}-\mathrm{BaO}-\mathrm{Al}_{2} \mathrm{O}_{3}$ phase diagram (12) a eutectic composition (melting point of $\sim 1300{ }^{\circ} \mathrm{C}$ ) exists within the $\mathrm{SiO}_{2}-\mathrm{BaAl}_{2} \mathrm{Si}_{2} \mathrm{O}_{8}-\mathrm{Al}_{6} \mathrm{Si}_{2} \mathrm{O}_{13}$ (silica-BAS-mullite) composition triangle, near the line connecting $\mathrm{SiO}_{2}$ and $\mathrm{BAS}$ (Fig. 8). This suggests that a eutectic can form by the reaction between $\mathrm{SiO}_{2}$ and BAS. Similar behavior is expected for the $\mathrm{SiO}_{2}-\mathrm{BSAS}$-mullite system, since Sr substitutes the sites of Ba in BSAS.

Table II Comparison of the composition of glass on the surface A \& B in Fig. 7(a) with the eutectic composition from the $\mathrm{SiO}_{2}-\mathrm{BaO}-\mathrm{Al}_{2} \mathrm{O}_{3}$ phase diagram (Wt.\%)

\begin{tabular}{|l|l|l|l|}
\hline & Surface A & Surface B & Eutectic \\
\hline $\mathrm{Al}_{2} \mathrm{O}_{3}$ & 16 & 20 & 15 \\
\hline $\mathrm{SiO}_{2}$ & 56 & 59 & 65 \\
\hline $\mathrm{BaO}$ & 22 & 18 & 20 \\
\hline $\mathrm{SrO}$ & 6 & 3 & -- \\
\hline
\end{tabular}

Table II compares the chemical composition of the glass on the surface at locations A \& B in Fig. 7(a) determined by electron microprobe analysis, with the eutectic composition from the $\mathrm{SiO}_{2}-\mathrm{BaO}-\mathrm{Al}_{2} \mathrm{O}_{3}$ phase diagram. The similar composition between the glass and the eutectic confirms that the glass is the product of $\mathrm{SiO}_{2}-\mathrm{BSAS}$ reaction. At $1482{ }^{\circ} \mathrm{C}$, a channel between the 
two glass layers is clearly visible (Fig. 7(b)), indicating that the molten glass formed at the $\mathrm{EBC} / \mathrm{SiC}$ interface moved to the surface. Modifier BSAS completely disappeared, and the top BSAS layer was significantly thinned at $1482{ }^{\circ} \mathrm{C}$. The high reactivity between $\mathrm{SiO}_{2}$ and BSAS, and the resulting severe glass formation, suggests that EBCs with the modified mullite layer should not be used for extended times at temperatures higher than $1400^{\circ} \mathrm{C}$.

Si/Mullite/BSAS EBC: Mullite alone (no modifier BSAS) can also be an effective chemical barrier between the $\mathrm{Si}$ and BSAS. Figure 9 is a cross section of $\mathrm{Si} /$ mullite/BSAS EBC on MI after $100 \mathrm{~h}$ in $90 \% \mathrm{H}_{2} \mathrm{O}$-balance $\mathrm{O}_{2}$ at $1300{ }^{\circ} \mathrm{C}(1 \mathrm{~h}$ cycles $)$, demonstrating excellent durability. Although significant diffusion between mullite and BSAS occurred at the mullite/BSAS interface, as indicated by the EDS spectra, it did not appear to have adversely affected the durability of the EBC. A similar mullite-BSAS reaction was observed in the $\mathrm{Si} /($ mullite+BSAS)/BSAS EBC system.

Cross-sections of $\mathrm{Si} /$ mullite/BSAS-coated $\mathrm{MI}$ from two different coating batches after $1000 \mathrm{~h}$ in $90 \% \mathrm{H}_{2} \mathrm{O}$-balance $\mathrm{O}_{2}$ at $1300{ }^{\circ} \mathrm{C}$ (1h cycles) are shown in Fig. 10. Figure 10(a) demonstrates that $\mathrm{Si} /$ mullite/BSAS EBC can be as durable as $\mathrm{Si} /($ mullite+BSAS)/BSAS EBC under these conditions, with excellent adherence and limited oxidation when the mullite remains crack-free. However, once cracks develop in the mullite (Fig. 10(b)) water vapor eventually penetrates through the coating, leading to accelerated degradation of EBC. The variation of performance between different batches indicates that precise control of coating parameters is critical in depositing crack-resistant mullite coatings.

Figures 11(a) and 11(b) are cross sections of mullite/BSAS EBC on SiC after 180h (20h thermal cycles) at $1400{ }^{\circ} \mathrm{C}$ and $20 \mathrm{~h}$ at $1500{ }^{\circ} \mathrm{C}$ (isothermal), respectively, in air. Under these conditions the BSAS degraded by forming a porous structure on the surface. Degradation was very severe at $1500{ }^{\circ} \mathrm{C}$, with the porous structure spreading over the entire BSAS layer. The cause of the degradation is not understood at this point. It should be noted that, in the absence of BSAS-silica contact, glasses did not develop in the mullite/BSAS system even at $1500^{\circ} \mathrm{C}$.

\subsection{Silica Volatility}

Figure 12 is a plot of weight change vs. time for uncoated and EBC-coated MI exposed to $1300{ }^{\circ} \mathrm{C}$ in the HPBR (6 atm, $\mathrm{pH}_{2} \mathrm{O} \sim 0.6$, gas velocity $\sim 24 \mathrm{~m} / \mathrm{sec}$ ). Each datum in the plot represents one thermal cycle, as the test was interrupted to measure sample weight. The measured linear weight loss of uncoated CVD SiC, as well as that of MI CMC, was due to the volatilization of silica by water vapor. The $\mathrm{Si} /($ mullite+BSAS)/BSAS and the $\mathrm{Si} / \mathrm{mullite} / \mathrm{BSAS}$ coated MI also showed a slight weight loss, presumably due to the volatilization of silica from BSAS. Cross-sections of the EBCs showed excellent coating adherence and minimal oxidation (Figs. 13(a) and 13(b)). Si/(Mullite+BSAS)/YSZ EBC-coated MI, on the other hand, exhibited thick scale and large pore formation after 50h (Fig. 13(c)). The large weight gain was due to water vapor enhanced oxidation as the water vapor penetrated through cracks in the EBC and attacked the substrate. Cracking was caused mainly by the large CTE mismatch between YSZ $\left(\sim 10 \times 10^{-6} /{ }^{\circ} \mathrm{C}\right)$ and mullite+BSAS $\left(5 \sim 6 \times 10^{-6} /{ }^{\circ} \mathrm{C}\right)$ and $\mathrm{YSZ}$ sintering. The poor performance of the $\mathrm{Si} /($ mullite+BSAS)/YSZ EBC demonstrates the effectiveness of BSAS in limiting water vapor penetration. 
The results of the TGA study are summarized in Figure 14. It is a plot of weight change vs. time for hot-pressed BSAS exposed to $50 \% \mathrm{H}_{2} \mathrm{O}$-balance $\mathrm{O}_{2}$ flowing at $4.4 \mathrm{~cm} / \mathrm{sec}$ from 1200 to $1500{ }^{\circ} \mathrm{C}$ at $1 \mathrm{~atm}$ total pressure. After initial weight drop, presumably due to buoyancy effect, linear weight loss was observed at all temperatures, with the rate $\left(k_{1}\right)$ increasing with temperature. The TGA experiments are a good model for temperature and water vapor partial pressure in an engine environment. However, engines operate at high total pressures. The flow rates encountered in a turbine engine are also much higher than the $4.4 \mathrm{~cm} / \mathrm{s}$ used in the TGA experiments. At higher flow rates and system pressures, silica volatility can be estimated by using equation [1], which assumes $\mathrm{Si}(\mathrm{OH})_{4}(\mathrm{~g})$ as the sole reaction product (2):

$$
\text { Volatility } \propto \frac{v^{1 / 2} \times P\left(\mathrm{H}_{2} \mathrm{O}\right)^{2}}{\left(P_{\text {TOTAL }}\right)^{1 / 2}}
$$

where $v$ is gas velocity, $\mathrm{P}\left(\mathrm{H}_{2} \mathrm{O}\right)$ is water vapor pressure, and $\mathrm{P}_{\text {TOTAL }}$ is total pressure. At $1300{ }^{\circ} \mathrm{C}$ in the TGA, the measured $k_{1}$ was $2.4 \times 10^{-4} \mathrm{mg} / \mathrm{cm}^{2}-\mathrm{h}$. Under the HPBR combustion condition of $1300{ }^{\circ} \mathrm{C}, v$ of $24 \mathrm{~m} / \mathrm{sec}, \mathrm{P}\left(\mathrm{H}_{2} \mathrm{O}\right)$ of $0.6 \mathrm{~atm}$, and $\mathrm{P}_{\text {TOTAL }}$ of $6 \mathrm{~atm}$, the calculated $k_{1}$ is 13.7 times the $k_{1}$ in the TGA condition. This increase is due to the much higher combustion gas velocity $\left(v^{1 / 2}\right.$ component in equation [1]). The HPBR rate estimated from the $1300{ }^{\circ} \mathrm{C}$ TGA data $\left(3.3 \times 10^{-3}\right.$ $\left.\mathrm{mg} / \mathrm{cm}^{2}-\mathrm{h}\right)$ agrees fairly well with the rate actually measured in the HPBR $\left(6 \times 10^{-3} \mathrm{mg} / \mathrm{cm}^{2}-\mathrm{h}\right)$. This confirms the validity of using equation [1] to convert the silica volatility from the low pressure-low velocity TGA test to the high pressure-high velocity HPBR conditions. It should be noted, however, that other volatile species could also possibly form from the reaction between BSAS and water vapor.

Table III Projected recession of BSAS after 1000h at $6 \mathrm{~atm}, \mathrm{pH}_{2} \mathrm{O}=0.6, \mathrm{~V}_{\mathrm{g}} \sim 24 \mathrm{~m} / \mathrm{sec}$, calculated using equation [1] and the silica volatility data from TGA

\begin{tabular}{|l|l|l|l|}
\hline Temperature $\left({ }^{\circ} \mathrm{C}\right)$ & 1300 & 1400 & 1500 \\
\hline Recession $(\mu \mathrm{m})$ & 28 & 67 & 268 \\
\hline
\end{tabular}

The projected recession of BSAS after $1000 \mathrm{~h}$ at 1300 to $1500{ }^{\circ} \mathrm{C}$ under HPBR conditions, calculated using equation [1] and the silica volatilities from the TGA test is listed in Table III. The assumptions used in the calculation are: (i) the weight loss during the early exposure as determined by TGA is solely due to the volatilization of silica from BSAS; (ii) BSAS that loses silica will eventually spall off. Mullite exposed in HPBR formed a porous alumina surface layer due to the selective loss of silica (5), most of which spalled off with time. Based on the assumptions, BSAS recession is the amount of BSAS, corresponding to the silica lost, divided by the density of BSAS. It is possible that some portion of the weight loss in the TGA may be due to loss of $\mathrm{BaO}$ or $\mathrm{SrO}$, whose water vapor stability is not known at this point, or due to spalling of BSAS after it loses silica. Therefore, the projected recession in Table III should be interpreted with an understanding that it is only intended to provide a rough projection on long-term recession rates. Recession becomes fairly significant, reaching $\sim 67 \mu \mathrm{m}$ at $1400{ }^{\circ} \mathrm{C}$. The $\mathrm{EBC}$ on Solar Turbines $\mathrm{SiC} / \mathrm{SiC}$ liners showed substantial BSAS recession in some areas after $14,000 \mathrm{~h}$ engine test (7). 


\subsection{BSAS Phase Stability}

BSAS Top Coat: The BSAS top coat was amorphous as-sprayed but converted readily to the hexagonal celsian phase after furnace exposure, with the conversion rate increasing with temperature (13). For example, hexagonal celsian phase was the dominant phase after $130 \mathrm{~min}$ in air at $1100^{\circ} \mathrm{C}$, and after less than $10 \mathrm{~min}$ at $1200^{\circ} \mathrm{C}$. In contrast, the conversion from hexagonalto-monoclinic celsian was much more sluggish and complex. The conversion was monitored by acquiring sequences of Raman spectra at intervals across the cross-section of the BSAS top coat in order to produce a "depth profile". The conversion was tracked by monitoring the peak areas for the most prominent peak for each phase $\left(A_{h}\right.$ and $\left.A_{m}\right)$, where $A_{h}$ is the area under the hexagonal celsian phase peak and $A_{m}$ is the area under the monoclinic celsian phase peak. $A$ peak area fraction was then calculated to represent the monoclinic fraction simply by $\mathrm{f}_{\text {monoclinic }}=$ $A_{m} /\left(A_{h}+A_{m}\right)$. Figure 15 shows the evolution of $f_{\text {monoclinic }}$ across the BSAS top coat thickness after $1,2,6$ and $24 \mathrm{~h}$ heat treatment at $1400{ }^{\circ} \mathrm{C}$. It was observed that the monoclinic phase nucleated at the outer surface and later near the bond coat interface, and the conversion slowly progressed inward from both surfaces.

$B S A S$ in (mullite+BSAS) Intermediate Coat: Raman analysis revealed the second phase BSAS (modifier BSAS) islands in the mullite to be extremely resistant to the hexagonal-tomonoclinic celsian phase conversion, much more so than BSAS top coat. For example, after $2 \mathrm{~h}$ at $1400^{\circ} \mathrm{C}$ in air, virtually all the BSAS islands remained hexagonal celsian. At the same time the BSAS top coat showed significant presence of the monoclinic phase. The only notable exception was that monoclinic phase appeared in islands that were adjacent to cracks in the coating generated during initial sectioning. Even after $24 \mathrm{~h}$ at $1400{ }^{\circ} \mathrm{C}$, which resulted in almost complete conversion of the top coat to monoclinic phase, a large fraction of the BSAS islands remained hexagonal phase. There seems to be a correlation between the larger, rounder islands converting to monoclinic phase and the smaller, thinner islands remaining hexagonal phase (Fig. 16). Additionally, BSAS islands near the BSAS top coat tended to convert to monoclinic.

\subsection{Thermal Conductivity}

The variation of thermal conductivity of (mullite+BSAS)/BSAS on MI with thermal exposure is shown in Figure 17. The thermal conductivity was measured as sprayed, after a $10 \mathrm{~h}$ furnace cycling $\left(1300{ }^{\circ} \mathrm{C}, 1 \mathrm{~h}\right.$ cycles, $90 \% \mathrm{H}_{2} \mathrm{O}$-balance $\left.\mathrm{O}_{2}\right)$, and after a $10 \mathrm{~h}$ furnace cycling followed by a $10 \mathrm{~h}$ laser cycling $\left(1482{ }^{\circ} \mathrm{C} \mathrm{EBC}\right.$ surface temperature and $1316^{\circ} \mathrm{C} \mathrm{EBC/CMC}$ interface temperature, $1 \mathrm{~h}$ cycles, air). There was a significant increase in thermal conductivity $(\sim 30 \%)$ after the initial $10 \mathrm{~h}$ furnace exposure, whereas the subsequent $10 \mathrm{~h}$ laser cycle testing reduced the conductivity. Sintering is believed to be responsible for the initial increase of thermal conductivity. The subsequent reduction in thermal conductivity is attributed to coating cracking and micro-delaminations under the high temperature, high thermal gradient cycling.

Figure 18 shows the variation of thermal conductivity of (mullite+BSAS)/BSAS on MI under extended, combined furnace and laser thermal cycling. The exposure consists of a $10 \mathrm{~h}$ furnace cycling $\left(1300{ }^{\circ} \mathrm{C}, 1 \mathrm{~h}\right.$ cycles, $90 \% \mathrm{H}_{2} \mathrm{O}$-balance $\left.\mathrm{O}_{2}\right)$ and a $10 \mathrm{~h}$ laser cycling $\left(1482{ }^{\circ} \mathrm{C} \mathrm{EBC}\right.$ surface temperature and $1316{ }^{\circ} \mathrm{C} \mathrm{EBC/CMC}$ interface temperature, $1 \mathrm{~h}$ cycles, air), followed by another $50 \mathrm{~h}$ furnace cycling and $50 \mathrm{~h}$ laser cycling. Although the thermal conductivity continued 
to decrease after the initial increase, down to $\sim 1.7 \mathrm{w} / \mathrm{m}-\mathrm{k}$ after 120 cycles, the rate of decrease substantially slowed down after the initial reduction. In contrast, the thermal conductivity of BSAS alone on MI, under the same combined furnace and laser thermal cycling, continued to increase, up to $\sim 3 \mathrm{w} / \mathrm{m}-\mathrm{k}$ after 100 cycles (14). Extensive glass formation was observed on the surface of BSAS EBC, which was believed to be responsible for the continued increase in thermal conductivity. This indicates potential detrimental effects of glass formation on the thermal insulation capability of EBC.

\section{DISCUSSION}

As Figs. 2 and 3 show, BSAS on Si-based ceramics reacts with thermally grown silica, forming a reaction zone and pores. The reaction zone, which is amorphous according to Raman spectroscopy (13), may be benign to coating durability as long as it remains solid. What is detrimental to the EBC durability is the formation of pores that continue to grow and eventually coalesce, causing EBC delamination. Pores are attributed to the bubbling of gaseous species through the scale as the scale viscosity is significantly reduced due to contamination by $\mathrm{Ba}, \mathrm{Sr}$, and $\mathrm{Al}(5,15)$. Gaseous species include $\mathrm{CO}$ or $\mathrm{CO}_{2}$, which are reaction products of the oxidation of $\mathrm{SiC}$ by oxygen, and silicon hydroxides such as $\mathrm{Si}(\mathrm{OH})_{4}$, reaction products of the oxidation of $\mathrm{SiC}$ by water vapor (1). Therefore, the BSAS-silica chemical incompatibility makes BSAS undesirable as an EBC when applied alone on Si-based ceramics.

Because of its low silica activity, low CTE, and crack resistance, BSAS is still attractive as an EBC as long as a suitable chemical barrier is available. Mullite or mullite modified by BSAS showed adequate chemical compatibility with BSAS and excellent bonding onto Si or Si-based ceramics. As Figs. 4 and 5 show, the Si/(mullite+BSAS)/BSAS EBC exhibits excellent durability out to $800 \mathrm{~h}$ at $1300{ }^{\circ} \mathrm{C}$ with limited BSAS-silica reaction and no pore formation. The improved chemical compatibility of the $\mathrm{Si} /($ mullite+BSAS)/BSAS EBC compared with the BSAS EBC is due to the limited BSAS-silica contact at the EBC/substrate interface. The BSAS-silica reaction was accelerated at higher temperatures as the kinetics of silica formation and the BSAS-silica reaction increased with temperature. At $\mathrm{T}>1400{ }^{\circ} \mathrm{C}$ the BSAS-silica reaction eventually produced a significant amount of low melting $\left(\sim 1300{ }^{\circ} \mathrm{C}\right) \mathrm{Al}_{2} \mathrm{O}_{3}-\mathrm{SiO}_{2}-\mathrm{BaO}-\mathrm{SrO}$ glasses, causing the spallation of the EBC (Fig. 7). The formation of low melting glasses is a key life-limiting factor for the $\mathrm{Si} /($ mullite $+\mathrm{BSAS}) / \mathrm{BSAS} \mathrm{EBC}$ system.

The $\mathrm{Si} /$ mullite/BSAS EBC can be as durable as the $\mathrm{Si} /($ mullite+BSAS)/BSAS EBC when the mullite layer remains crack-free. A major disadvantage of the mullite intermediate coat compared with the mullite+BSAS intermediate coat is the difficulty in depositing crack-free mullite. The development of cracks is attributed to residual amorphous phases in the as-sprayed mullite and their subsequent crystallization in thermal exposure $(5,8)$, and the slightly higher CTE of mullite $\left(5-6 \times 10^{-6} /{ }^{\circ} \mathrm{C}\right)$ compared to $\mathrm{SiC}\left(4-5 \times 10^{-6} /{ }^{\circ} \mathrm{C}\right)$. The fact that $\mathrm{CTE}$ is an intrinsic material property, whereas the deposition of amorphous mullite is sensitive to process variation, implies that residual amorphous mullite may be the key contributor to the cracking. A major advantage of the mullite intermediate coat compared with the mullite+BSAS intermediate coat is the absence of low melting glass formation. In the absence of glass formation, however BSAS suffers a different type of degradation at $\mathrm{T}>1400{ }^{\circ} \mathrm{C}$, i.e., the formation of a porous structure which is likely to be a key life-limiting factor. 
The superior crack resistance of mullite+BSAS compared to mullite is responsible for the superior environmental durability of EBCs containing the mullite+BSAS intermediate coat. BSAS was originally added in mullite with a hypothesis that the low CTE monoclinic celsian $\left(4-5 \times 10^{-6} /{ }^{\circ} \mathrm{C}\right)$ would improve the crack resistance of the mullite intermediate coat by lowering the CTE. The discovery that the high CTE hexagonal celsian $\left(\sim 8 \times 10^{-6} /{ }^{\circ} \mathrm{C}\right)$ is the dominant phase in the mullite+BSAS intermediate coat, even after over $200 \mathrm{~h}$ at $1300{ }^{\circ} \mathrm{C}$, indicates that some mechanism other than CTE modification may be responsible for the superior crack resistance of the mullite+BSAS intermediate coat. A possible mechanism is stress state modification by the addition of low modulus BSAS. Without knowing the mechanism by which the modifier BSAS improves the crack resistance of mullite, it is not clear which form of BSAS is more desirable. In an effort to elucidate the mechanism by which modifier BSAS improves the crack resistance of mullite, an investigation is underway to determine the variation of stresses in EBCs under thermal exposure and its effects on coating performance.

Silica volatility of BSAS is another key life-limiting factor for both $\mathrm{Si} /$ mullite/BSAS and $\mathrm{Si} /($ mullite+BSAS)/BSAS EBC systems. Projected recession of BSAS after $1000 \mathrm{~h}$ under typical NASA HPBR conditions, calculated using a silica volatility model (2) and the silica volatility data from the TGA test, was $28 \mu \mathrm{m}, 67 \mu \mathrm{m}$, and $268 \mu \mathrm{m}$ at $1300{ }^{\circ} \mathrm{C}, 1400{ }^{\circ} \mathrm{C}$, and $1500{ }^{\circ} \mathrm{C}$, respectively. The recession will be even higher in typical engines that run at higher pressures and gas velocities. For BSAS thickness of $\sim 250 \mu \mathrm{m}$ (10 mil), typical thickness of YSZ in current TBCs in aero gas turbines, the volatility of BSAS will be a key durability issue if used for several thousand hours at $\mathrm{T}>1400{ }^{\circ} \mathrm{C}$.

The thermal insulation capability of an EBC depends on its thermal conductivity, thickness and the applied heat flux. Figures 19(a) and 19(b) are plots of temperature drop across the EBC vs. the coating thermal conductivity for heat fluxes of $50 \mathrm{~W} / \mathrm{cm}^{2}$ and $100 \mathrm{~W} / \mathrm{cm}^{2}$, respectively. Note that the temperature drop increased with increasing EBC thickness or heat flux. Based on the thermal conductivity of as-received (mullite+BSAS)/BSAS EBC $(\sim 1.7 \mathrm{w} / \mathrm{m}-\mathrm{k}), \sim 500 \mu \mathrm{m}$ $(20 \mathrm{mil})$ thick $\mathrm{EBC}$ is required to create a $167^{\circ} \mathrm{C}\left(300^{\circ} \mathrm{F}\right)$ temperature drop at a heat flux of $50 \mathrm{~W} / \mathrm{cm}^{2}$, and $\sim 250 \mu \mathrm{m}(10 \mathrm{mil})$ thick $\mathrm{EBC}$ at $100 \mathrm{~W} / \mathrm{cm}^{2}$. After extended exposure a significant increase in thermal conductivity is expected due to the degradation of the EBC via sintering and glass formation. In order to accurately project the rate of sintering and glass formation in engine environments and their effect on EBC thermal conductivity, long-term laser thermal cycling in steam environments with a properly applied temperature gradient is necessary.

Chemical compatibility, environmental durability, and silica volatility all suggest that the upper temperature limit of EBCs based on mullite and BSAS for several thousand hours of life is $\sim 1400{ }^{\circ} \mathrm{C}$. Since the EBC/CMC interface will experience a lower temperature than the EBC surface in gas turbines, due to the temperature gradient through the EBC, the BSAS-silica reaction may not be as critical as the degradation of BSAS top coat via the formation of a porous structure and silica volatilization. More accurate life projection needs the characterization of EBCs under temperature gradient in steam environments. 


\section{CONCLUSIONS}

Although attractive as an EBC because of its low silica activity and low CTE, BSAS is not a viable $\mathrm{EBC}$ on its own because of severe reaction with silica, forming pores at temperatures as low as $1200^{\circ} \mathrm{C}$. BSAS can still be an effective EBC if used with a suitable chemical barrier such as mullite or mullite+BSAS. The $\mathrm{Si} /($ mullite+BSAS) /BSAS EBC system is more robust than the $\mathrm{Si} /$ mullite/BSAS EBC because of the superior crack resistance of the mullite+BSAS intermediate coat. Thorough characterization suggests that the upper temperature limit of EBCs based on mullite and BSAS for several thousand hours of life is $\sim 1400^{\circ} \mathrm{C}$. Key life-limiting factors at $\mathrm{T}>$ $\sim 1400{ }^{\circ} \mathrm{C}$ are silica volatilization from BSAS, BSAS degradation by the formation of a porous structure, and glass formation due to BSAS-silica reaction. The development of EBCs with higher temperature capability and lower thermal conductivity than current state-of-the art EBCs is necessary to realize the full potential of Si-based ceramics in next generation gas turbine engines.

\section{REFERENCES}

1. E.J. Opila and R. Hann, "Paralinear Oxidation of CVD SiC in Water Vapor," J. Am. Ceram. Soc., 80 [1] 197-205 (1997).

2. J.L. Smialek, R.C. Robinson, E.J. Opila, D.S. Fox, and N.S. Jacobson, "SiC and $\mathrm{Si}_{3} \mathrm{~N}_{4}$ Scale Volatility under Combustor Conditions," Adv. Composite Mater., 8 [1] 33-45 (1999).

3. K.L. More, P.F. Tortorelli, M.K. Ferber, L.R. Walker, J.R. Keiser, N. Miriyala, W.D. Brentnall, and J.R. Price, "Exposure of Ceramics and Ceramic Matrix Composites in Simulated and Actual Combustor Environments," ASME paper 99-GT-292, presented at the International Gas Turbine and Aeroengine Congress and Exposition, Indianapolis, IN, USA, June 7-10, 1999.

4. M.K. Ferber, H.T. Lin, V. Parthasarathy, and W.D. Brentnall, "Degradation of Silicon Nitrides in High Pressure, Moisture Rich Environments," ASME paper 99-GT-265, presented at the International Gas Turbine and Aeroengine Congress and Exposition, Indianapolis, IN, USA, June 7-10, 1999.

5. K.N. Lee, "Key Durability Issues with Mullite-Based Environmental Barrier Coatings for SiBased Ceramics," Transactions of the ASME, 122 632-636 (2000).

6. K.N. Lee, Surface and Coatings Technology, "Current Status of Environmental Barrier Coatings for Si-Based Ceramics," 133-134 1-7 (2000).

7. H.E. Eaton, G.D. Linsey, E.Y. Sun, K.L. More, J.B. Kimmel, J.R. Price, and N. Miriyala, "EBC Protection of $\mathrm{SiC} / \mathrm{SiC}$ Composites in the Gas Turbine Combustion Environment Continuing Evaluation and Refurbishment Considerations," ASME TURBOEXPO 2001, June 4-7, 2001, New Orleans, Louisiana, ASME 2001-GT-0513.

8. K.N. Lee, R.A. Miller, and N.S. Jacobson, "New Generation of Plasma-Sprayed Mullite Coatings on Silicon-Carbide," J. Am. Ceram. Soc., 78 [3] 705-710 (1995).

9. D. Brewer, "HSR/EPM Combustor Materials Development Program," Materials Science and Engineering, A261 284-291 (1999).

10. R.C. Robinson and J.L. Smialek, "SiC Recession Caused by $\mathrm{SiO}_{2}$ Scale Volatility under Combustion Conditions: I, Experimental Results and Empirical Model," J. Am. Ceram. Soc., 82 [7] 1817-25 (1999). 
11. D. Zhu and R.A. Miller, "Thermal Conductivity and Elastic Modulus Evolution of Thermal Barrier Coatings under High Heat Flux Conditions," J. Thermal Spray Tech., 9 [2] 175-180 (2000).

12. Phase Equilibria Diagrams, CD-ROM Database Version 2.1, The American Ceramic Society, Westerville, $\mathrm{OH}, 1998$.

13. J.I. Eldridge and K.N. Lee, "Phase Evolution of BSAS in Environmental Barrier Coatings," pp. 383-390 in Ceramic Engineering \& Science Proceedings, Vol. 22 [4], Edited by M. Singh and T. Jessen, The American Ceramic Society, Westerville, OH, 2001.

14. D. Zhu, K.N. Lee, and R.A. Miller, "Thermal Conductivity and Thermal Gradient Cyclic Behavior of Refractory Silicate Coatings on $\mathrm{SiC} / \mathrm{SiC}$ Ceramic Matrix Composites," pp. 443452 in Ceramic Engineering \& Science Proceedings, Vol. 22 [4], Edited by M. Singh and T. Jessen, The American Ceramic Society, Westerville, OH, 2001.

15. K.N. Lee, "Contamination Effects on Interfacial Porosity during Cyclic Oxidation of MulliteCoated Silicon Carbide," J. Am. Ceram. Soc., 81 [12] 3329-32 (1998).

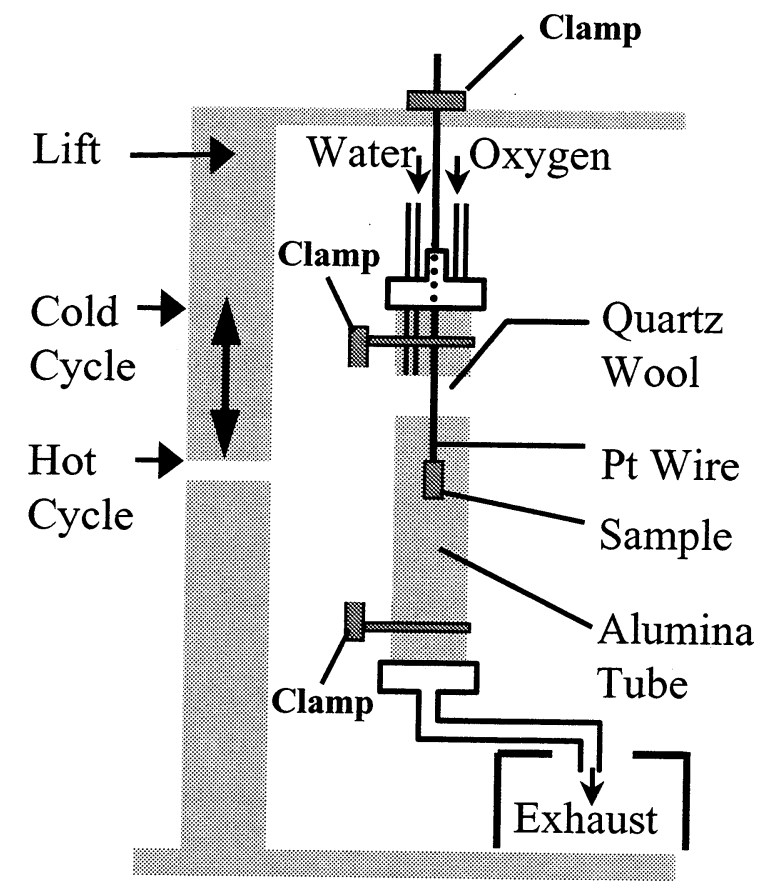

Fig. 1 Schematic of automated water vapor thermal cycling furnace 

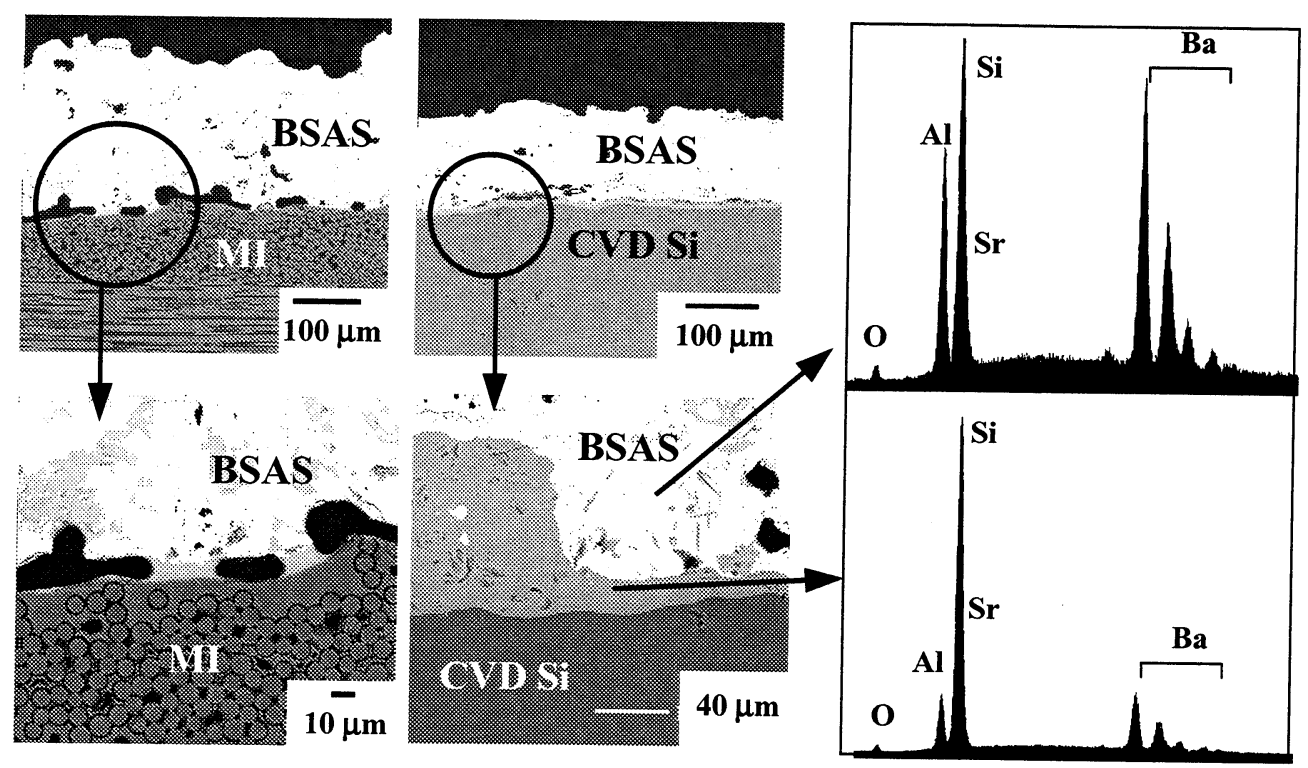

Fig. 2 Cross-section and EDS analysis of MI and CVD Si coated with BSAS after a 100h isothermal exposure at $1300^{\circ} \mathrm{C}$ in air
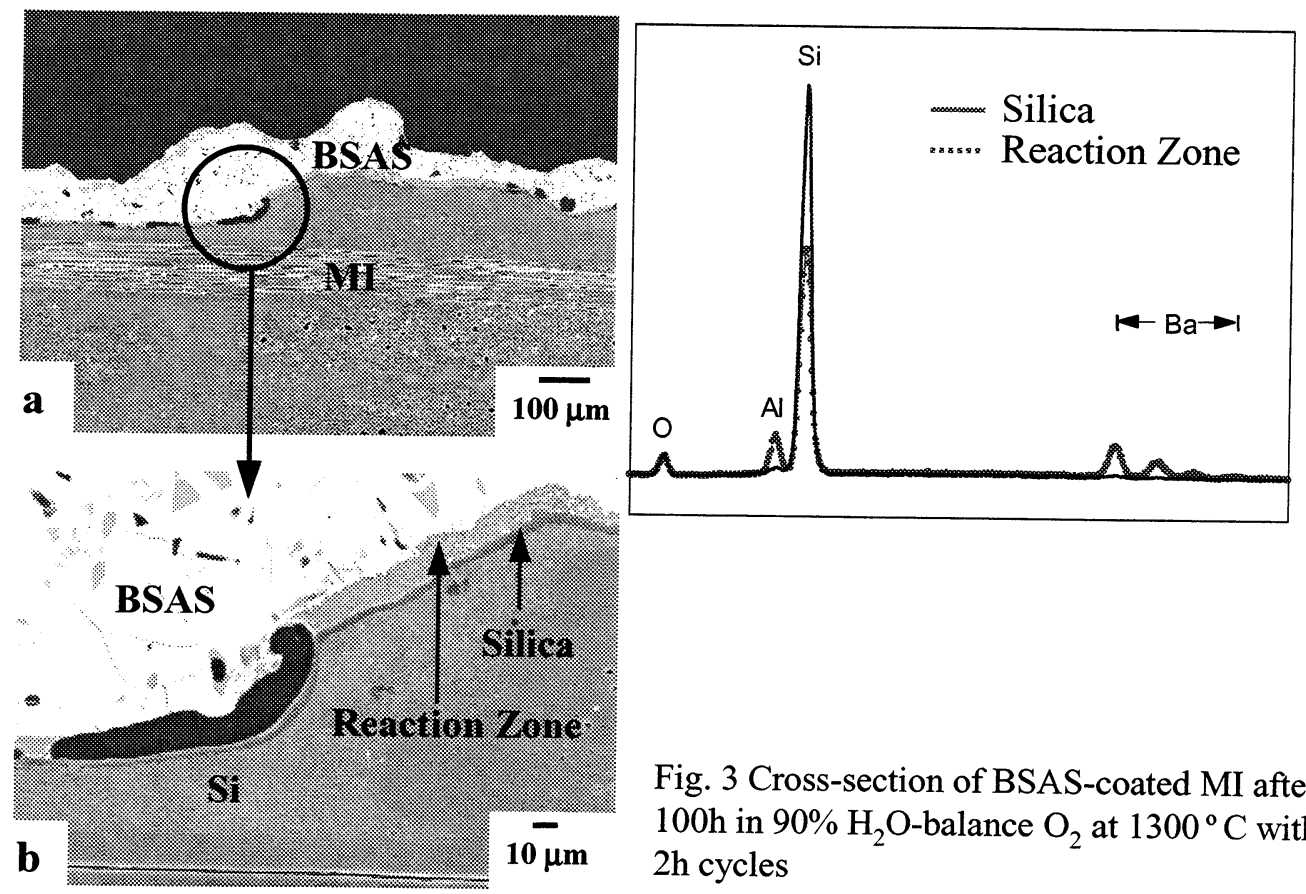

Fig. 3 Cross-section of BSAS-coated MI after $100 \mathrm{~h}$ in $90 \% \mathrm{H}_{2} \mathrm{O}$-balance $\mathrm{O}_{2}$ at $1300^{\circ} \mathrm{C}$ with $2 \mathrm{~h}$ cycles 

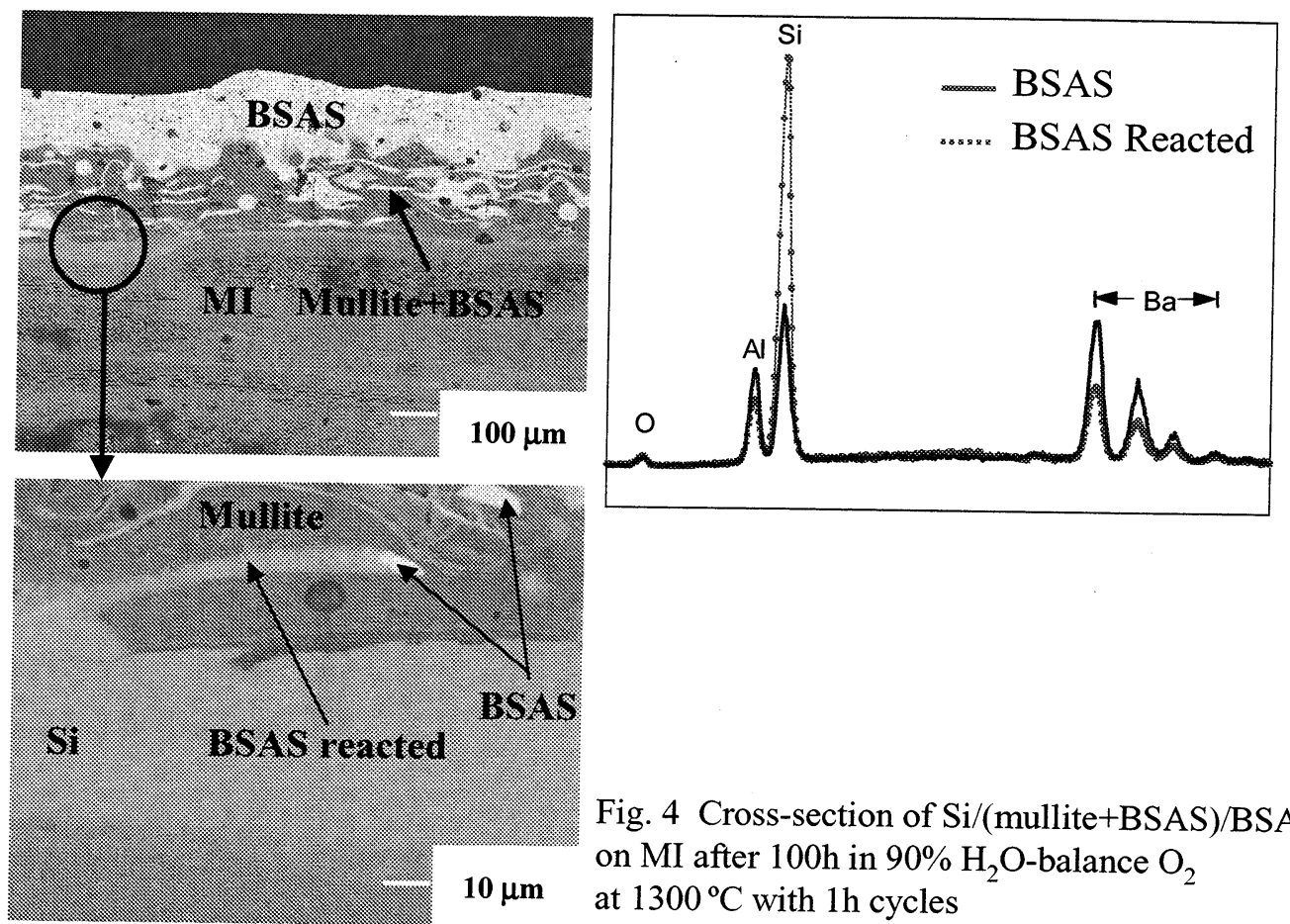

Fig. 4 Cross-section of $\mathrm{Si} /($ mullite+BSAS)/BSAS on $\mathrm{MI}$ after $100 \mathrm{~h}$ in $90 \% \mathrm{H}_{2} \mathrm{O}$-balance $\mathrm{O}_{2}$ at $1300^{\circ} \mathrm{C}$ with $1 \mathrm{~h}$ cycles

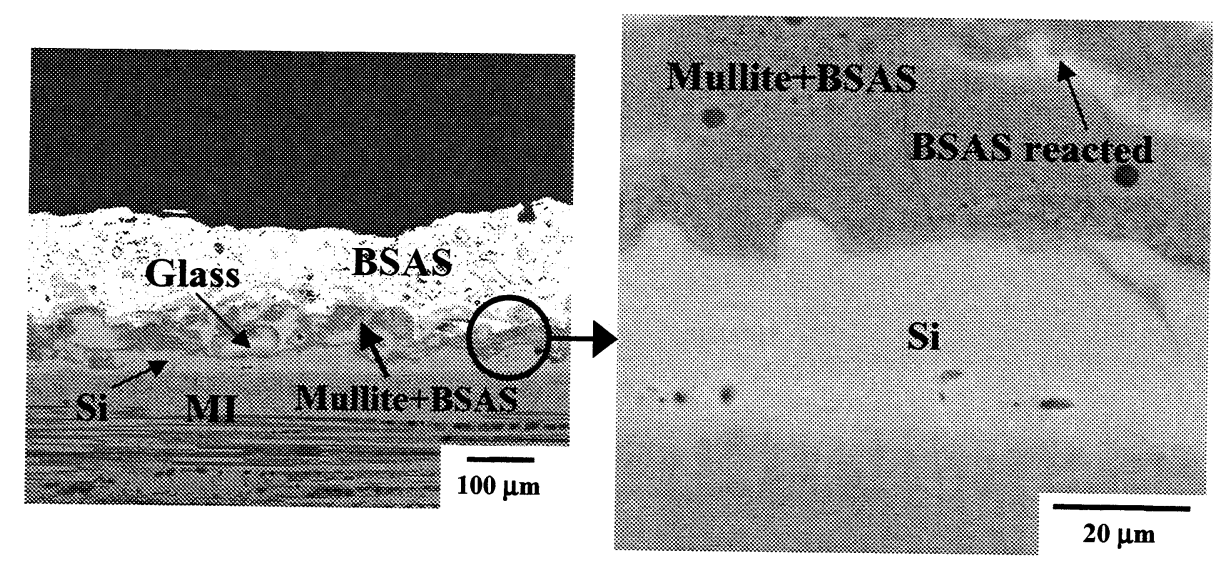

Fig. 5 Cross-section of Si/(mullite+BSAS)/BSAS on MI after $800 \mathrm{~h}$ in $90 \% \mathrm{H}_{2} \mathrm{O}$ balance $\mathrm{O}_{2}$ at $1300^{\circ} \mathrm{C}$ with $1 \mathrm{~h}$ cycles 


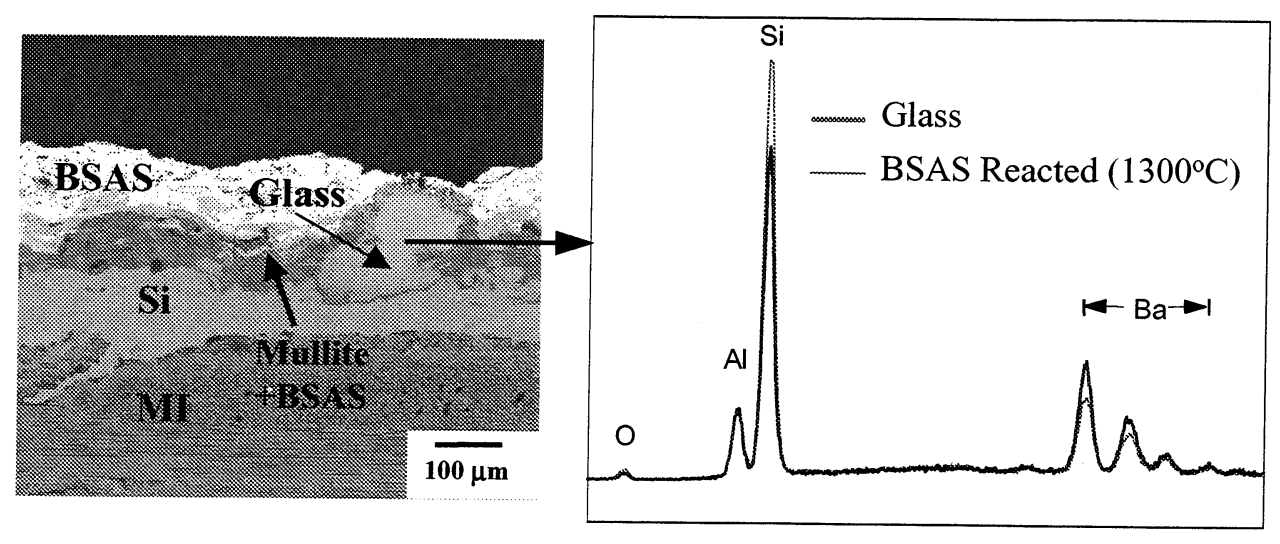

Fig. 6 Cross-section of $\mathrm{Si} /($ mullite $+\mathrm{BSAS}) / \mathrm{BSAS}$ on $\mathrm{MI}$ after $300 \mathrm{~h}$ in $90 \% \mathrm{H}_{2} \mathrm{O}$ balance $\mathrm{O}_{2}$ at $1400{ }^{\circ} \mathrm{C}$ with $1 \mathrm{~h}$ cycles

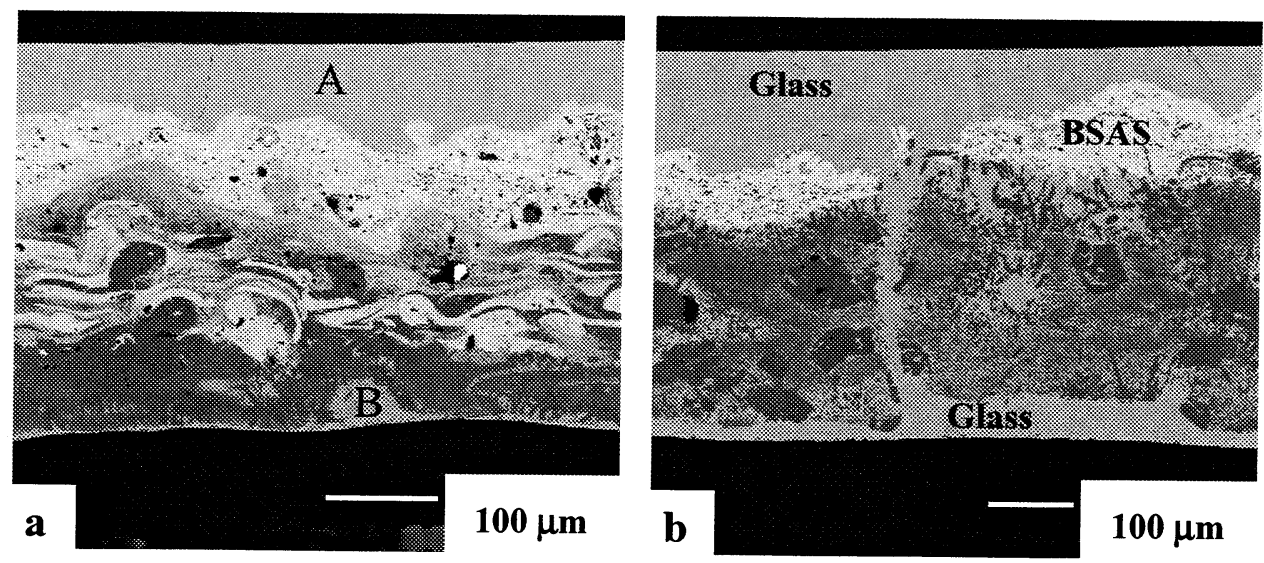

Fig. 7 Cross-sections of (mullite+BSAS)/BSAS EBC on SiC after thermal exposure (a: $20 \mathrm{~h}, 1440{ }^{\circ} \mathrm{C}$, isothermal, air; b: $100 \mathrm{~h}, 1480{ }^{\circ} \mathrm{C}$ - $1 \mathrm{~h}$ cycles, $90 \% \mathrm{H}_{2} \mathrm{O}$-balance $\mathrm{O}_{2}$ ) 


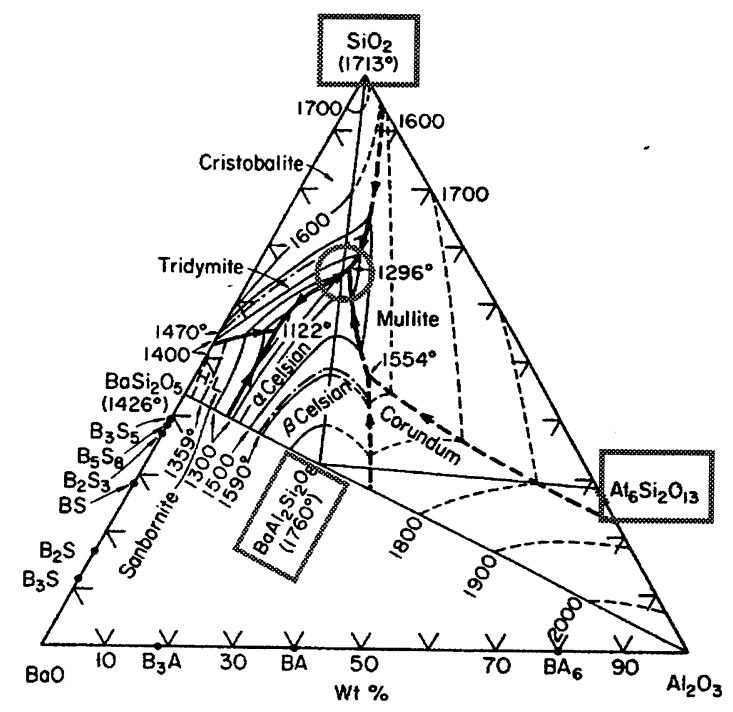

Fig. $8 \mathrm{SiO}_{2}-\mathrm{BaO}-\mathrm{Al}_{2} \mathrm{O}_{3}$ Phase Diagram

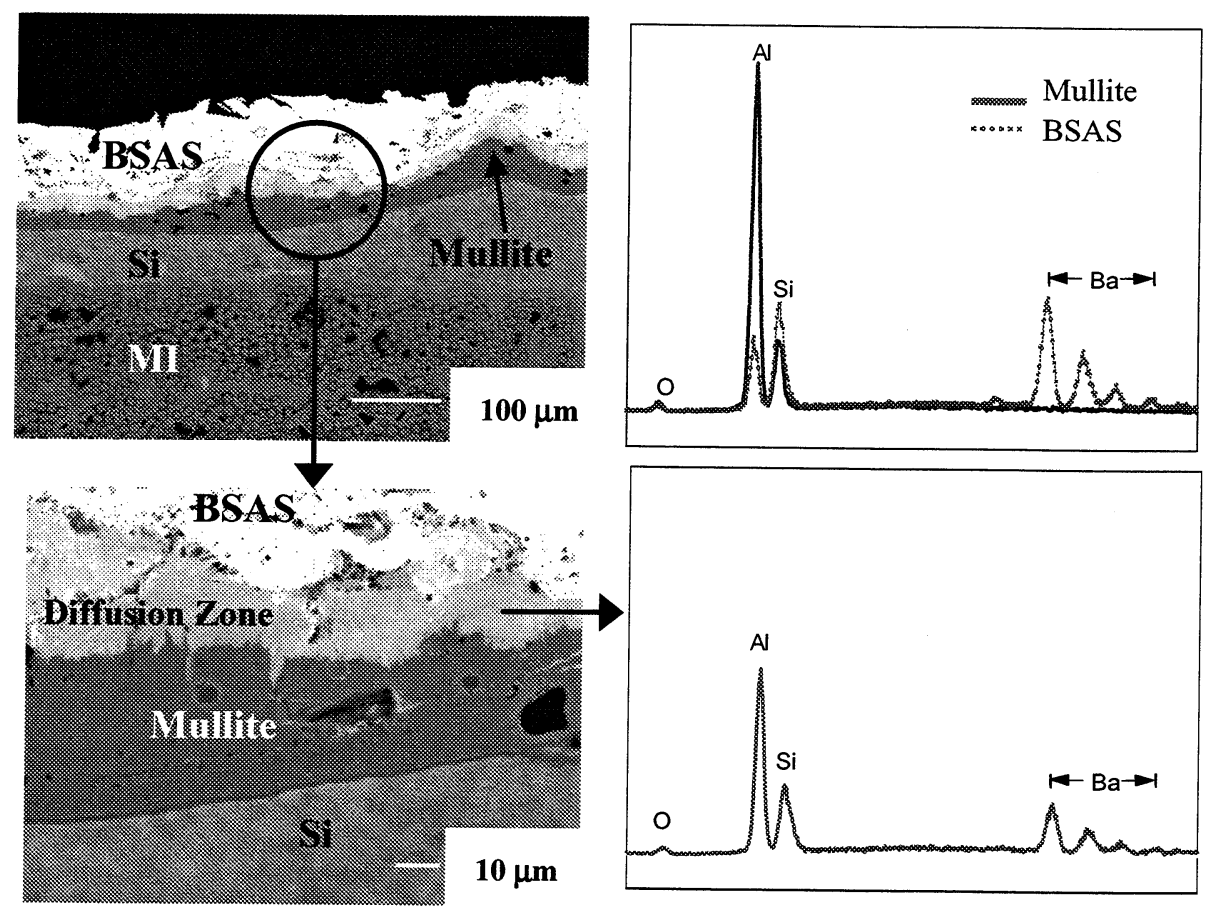

Fig. 9 Cross-section of $\mathrm{Si} /$ mullite/BSAS on $\mathrm{MI}$ after $100 \mathrm{~h}$ in $90 \% \mathrm{H}_{2} \mathrm{O}$-balance $\mathrm{O}_{2}$ at $1300^{\circ} \mathrm{C}$ with $1 \mathrm{~h}$ cycles 

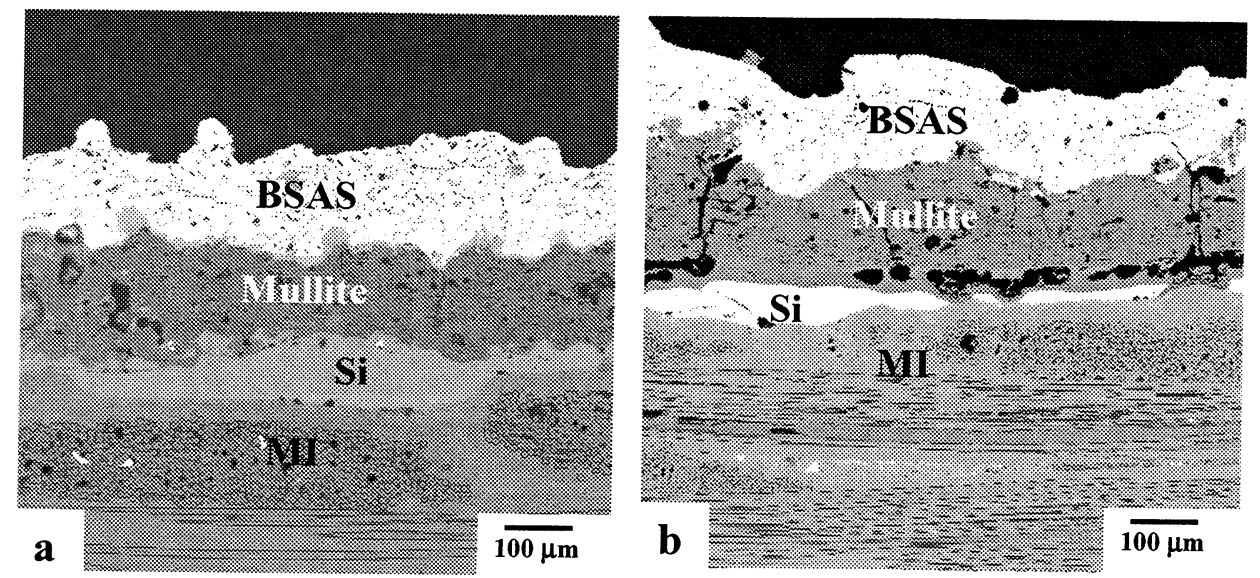

Fig. 10 Cross-section of $\mathrm{Si} /$ mullite/BSAS on $\mathrm{MI}$ after $1000 \mathrm{~h}$ in $90 \% \mathrm{H}_{2} \mathrm{O}$-balance $\mathrm{O}_{2}$ at $1300^{\circ} \mathrm{C}$ with $1 \mathrm{~h}$ cycles (a and $\mathrm{b}$ are from two different batches of coatings)
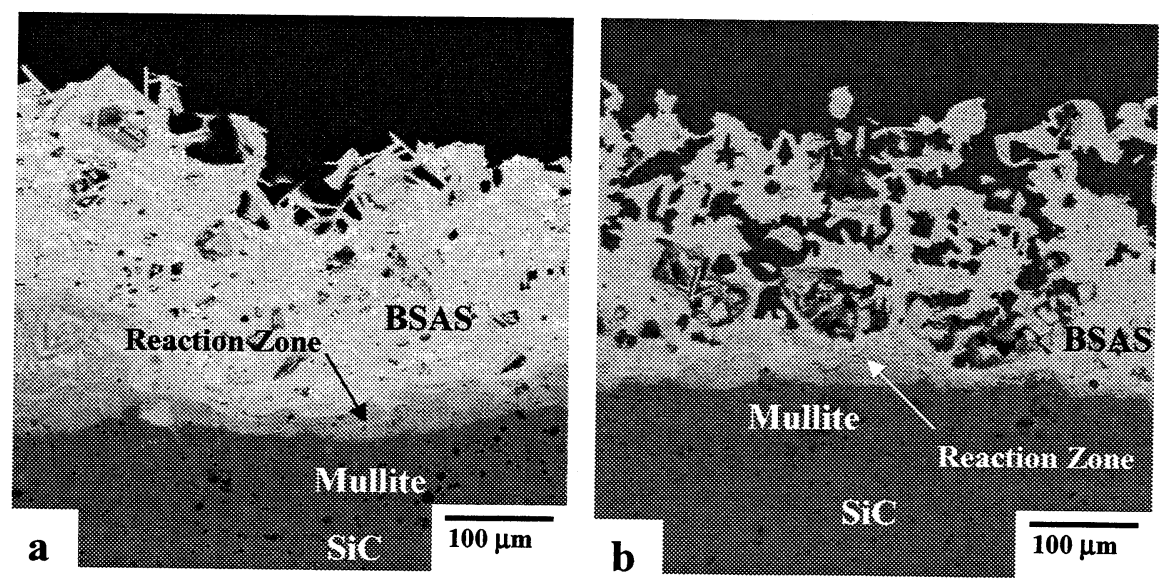

Fig. 11 Cross-section of mullite/BSAS on $\mathrm{SiC}$ after high temperature exposure in air (a: $180 \mathrm{~h}, 1400^{\circ} \mathrm{C}-20 \mathrm{~h}$ cycles; b: $\left.20 \mathrm{~h}, 1500^{\circ} \mathrm{C}\right)$ 


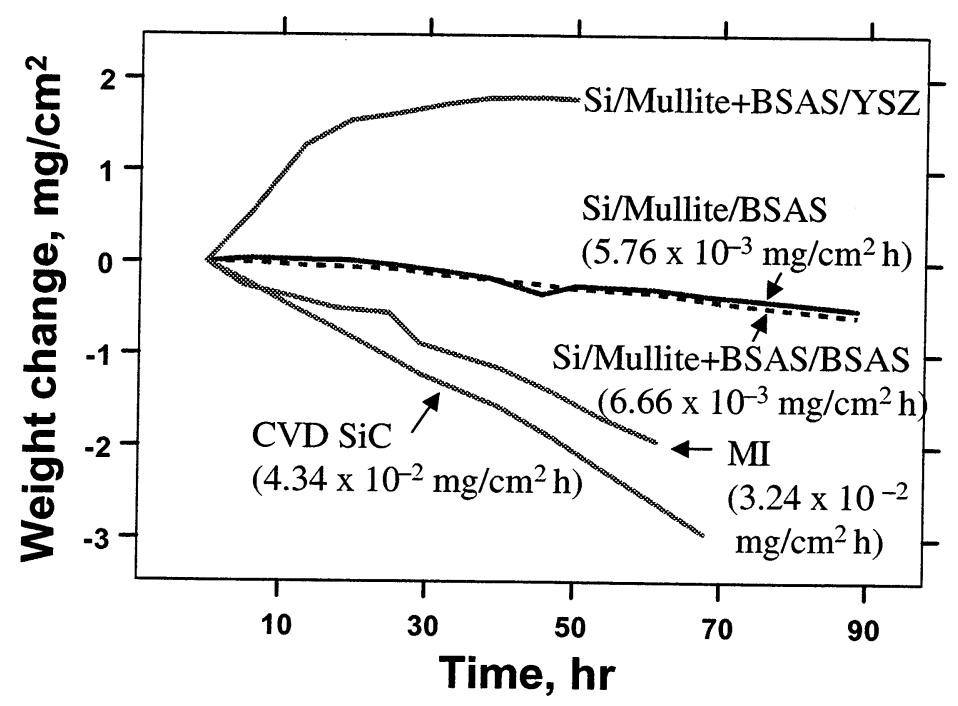

Fig. 12 The plot of weight change vs. time for uncoated and $\mathrm{EBC}$-coated $\mathrm{SiC}$ exposed in high pressure burner rig $\left(1300^{\circ} \mathrm{C}, 6 \mathrm{~atm}, \mathrm{pH}_{2} \mathrm{O} \sim 0.6\right.$, gas velocity $\sim 24 \mathrm{~m} / \mathrm{sec}$, fuel to air ratio $=0.065$ )
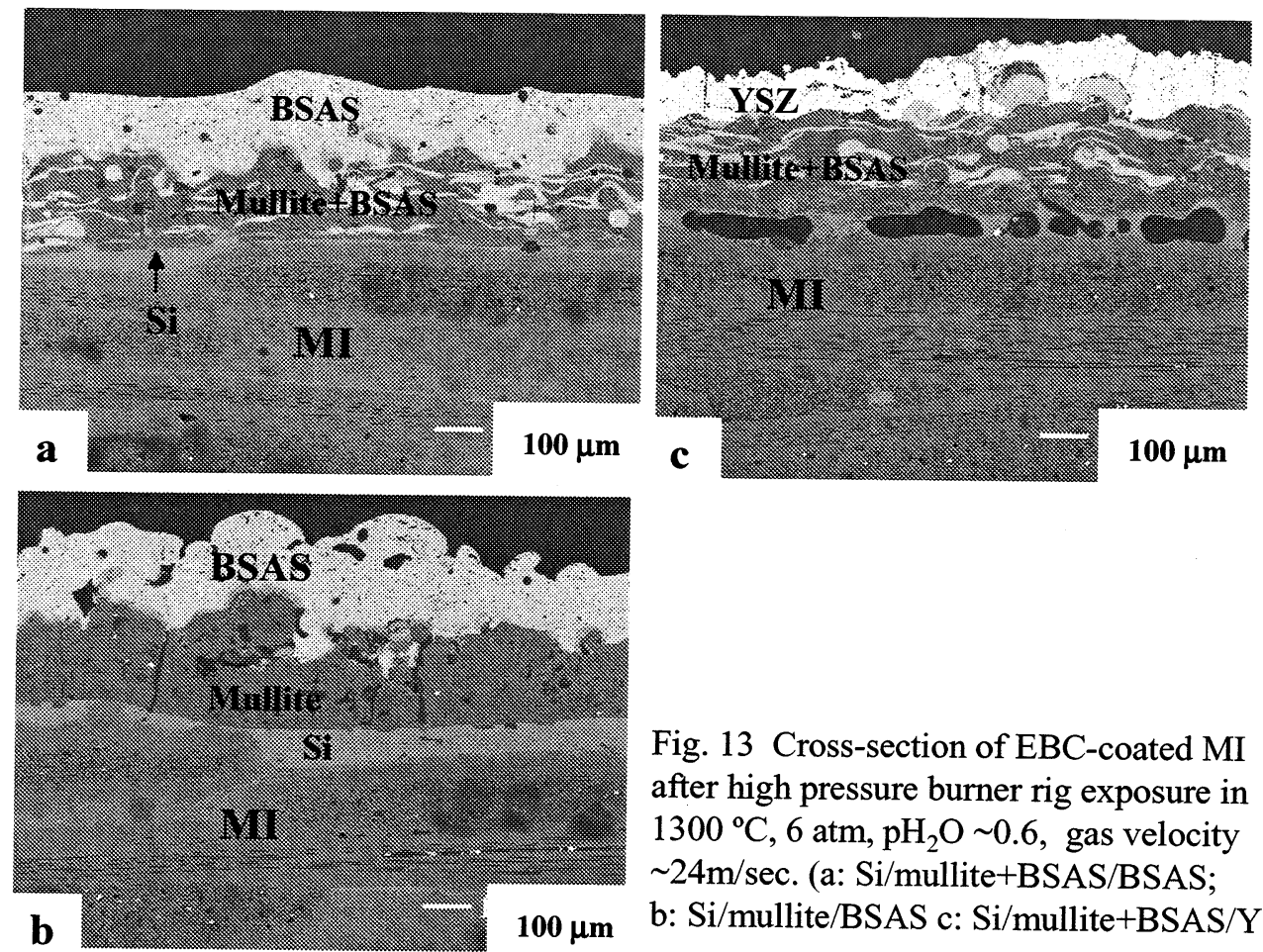

Fig. 13 Cross-section of EBC-coated MI after high pressure burner rig exposure in $1300^{\circ} \mathrm{C}, 6 \mathrm{~atm}, \mathrm{pH}_{2} \mathrm{O} \sim 0.6$, gas velocity $\sim 24 \mathrm{~m} / \mathrm{sec}$. (a: $\mathrm{Si} /$ mullite+BSAS/BSAS; b: Si/mullite/BSAS c: Si/mullite+BSAS/YSZ) 


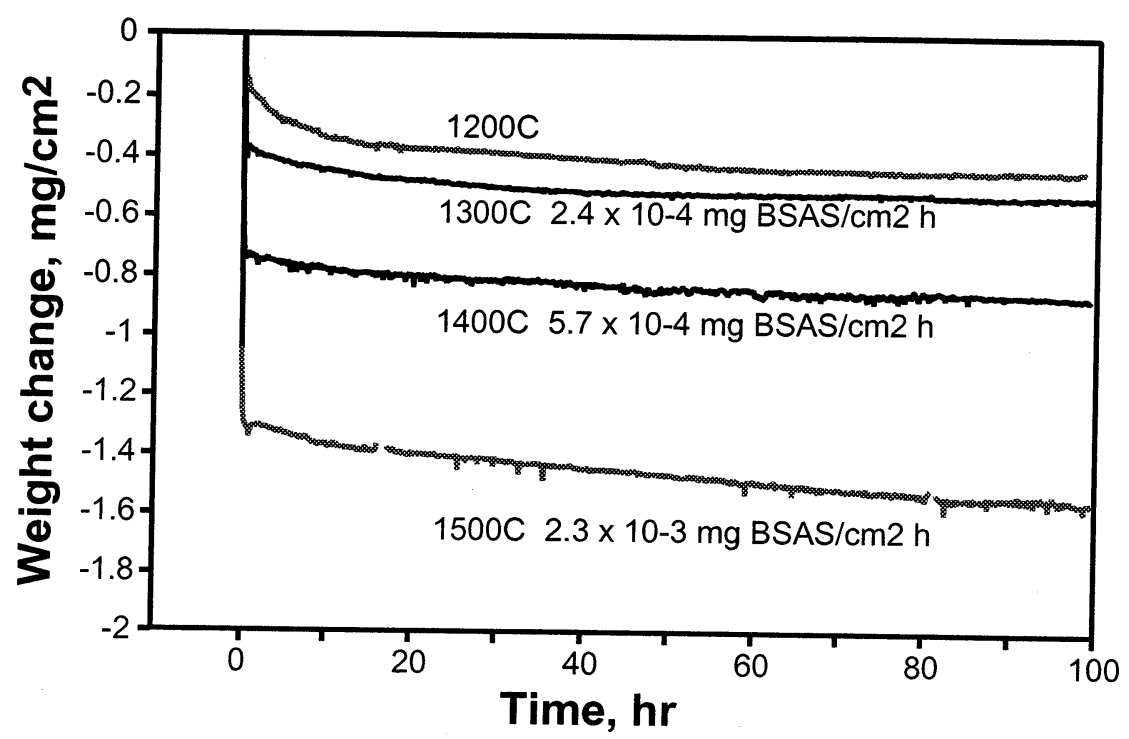

Fig. 14 The plot of weight change vs. time for hot pressed BSAS in TGA $\left(1200^{\circ} \mathrm{C}-1500^{\circ} \mathrm{C}, 1 \mathrm{~atm}, \mathrm{pH}_{2} \mathrm{O}=0.5\right.$, gas velocity $\left.=4.4 \mathrm{~cm} / \mathrm{sec}\right)$

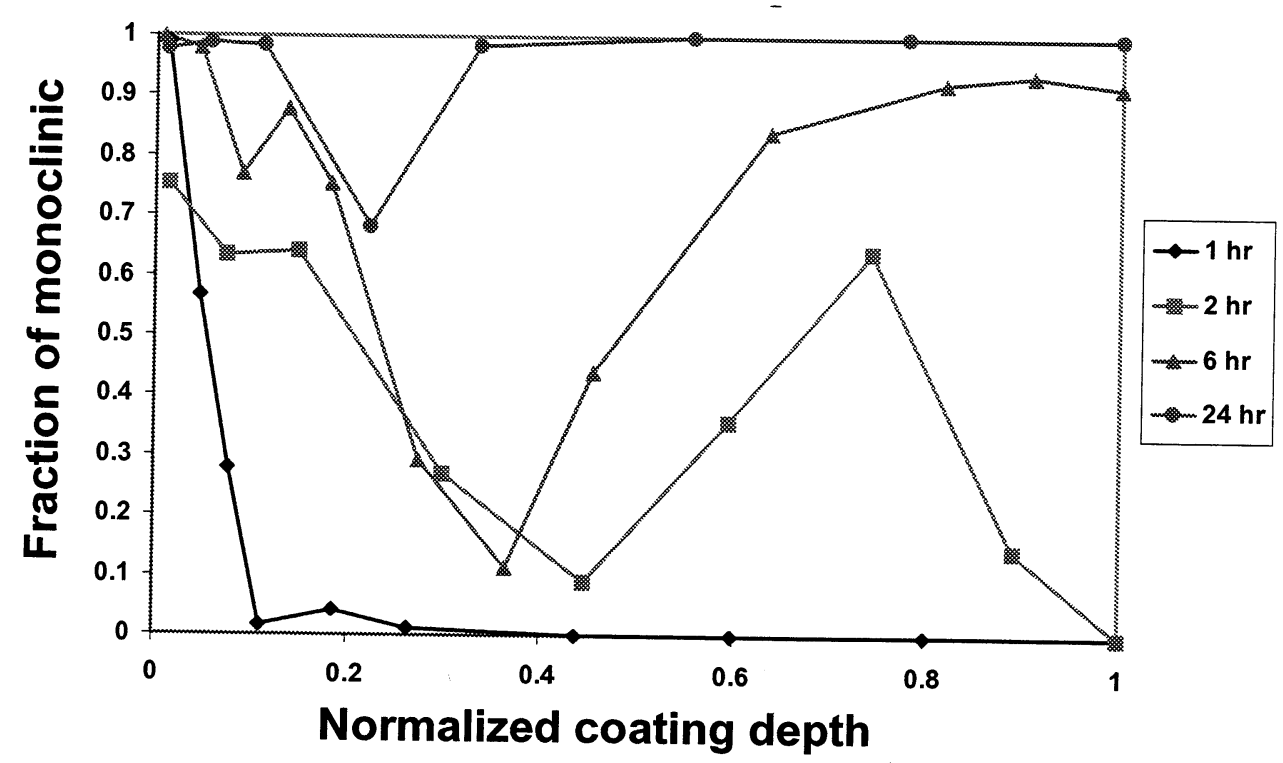

Fig. 15 The evolution of $\mathrm{f}_{\text {monoclinic }}$ across the BSAS top coat thickness after heat treatment at $1400^{\circ} \mathrm{C}$ in air 


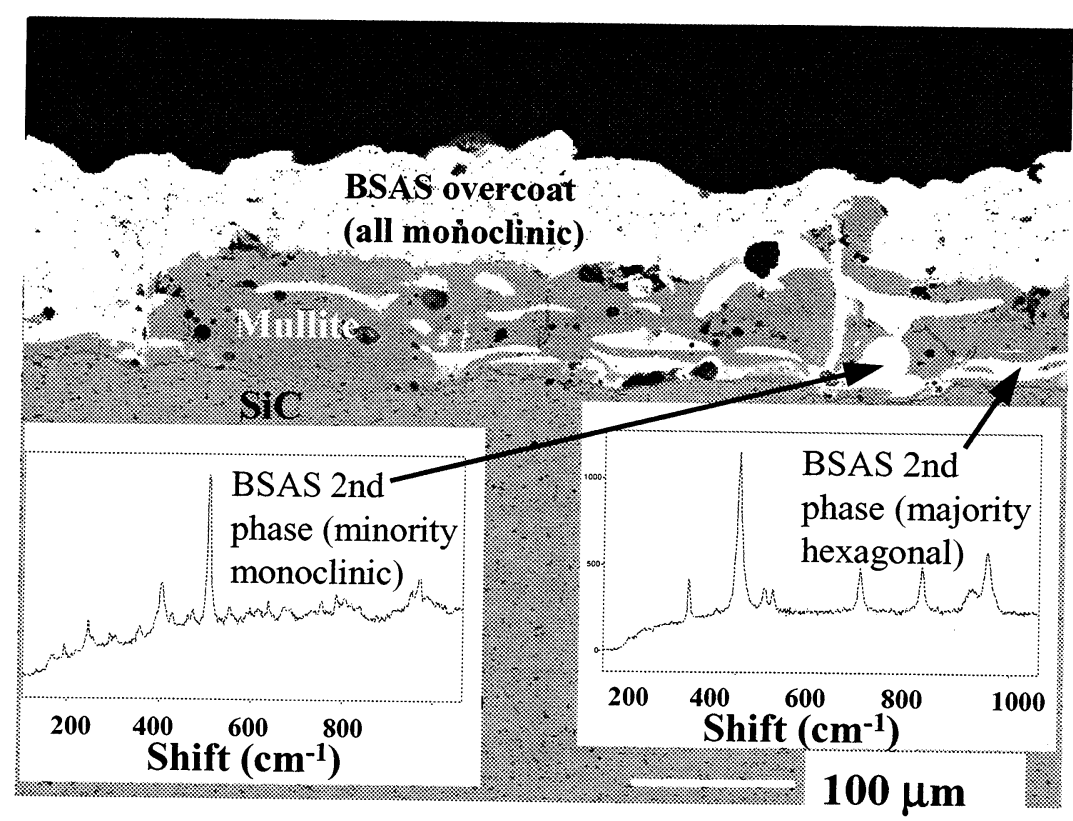

Fig. 16 BSAS phase after $200 \mathrm{~h}$ in $90 \% \mathrm{H}_{2} \mathrm{O}$-balance $\mathrm{O}_{2}$ at $1300{ }^{\circ} \mathrm{C}$ with $1 \mathrm{~h}$ cycles

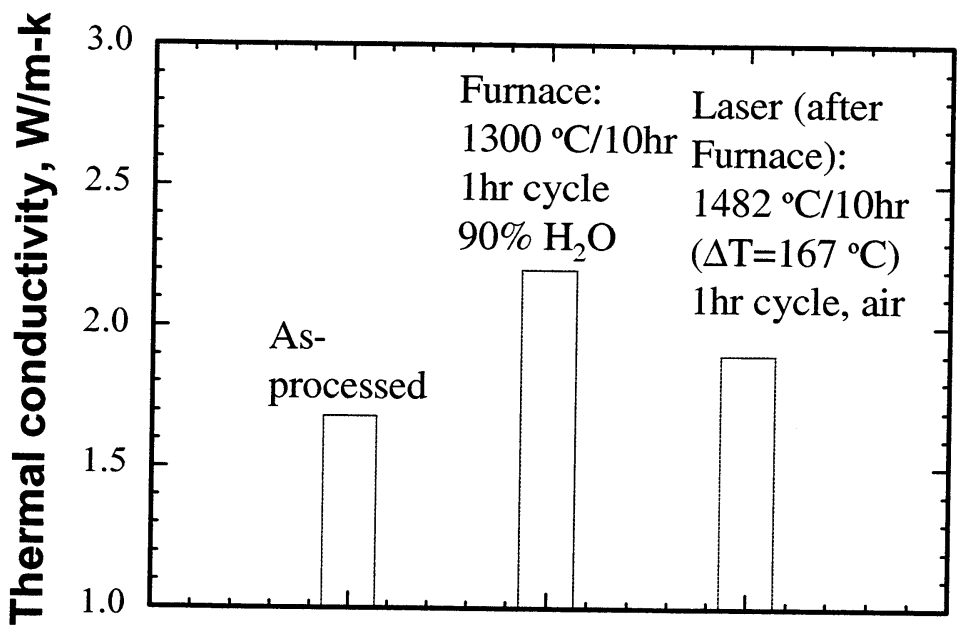

Fig. 17 Effect of thermal cycling on the thermal conductivity of mullite+BSAS/BSAS on MI $\left(10-1 \mathrm{~h}\right.$ furnace cycles at $1300^{\circ} \mathrm{C}$ followed by $101 \mathrm{~h}$ laser cycles at $1482^{\circ} \mathrm{C} \mathrm{EBC}$ surface temperature and $1316^{\circ} \mathrm{C} \mathrm{EBC/MI} \mathrm{interface} \mathrm{temperature)}$ 


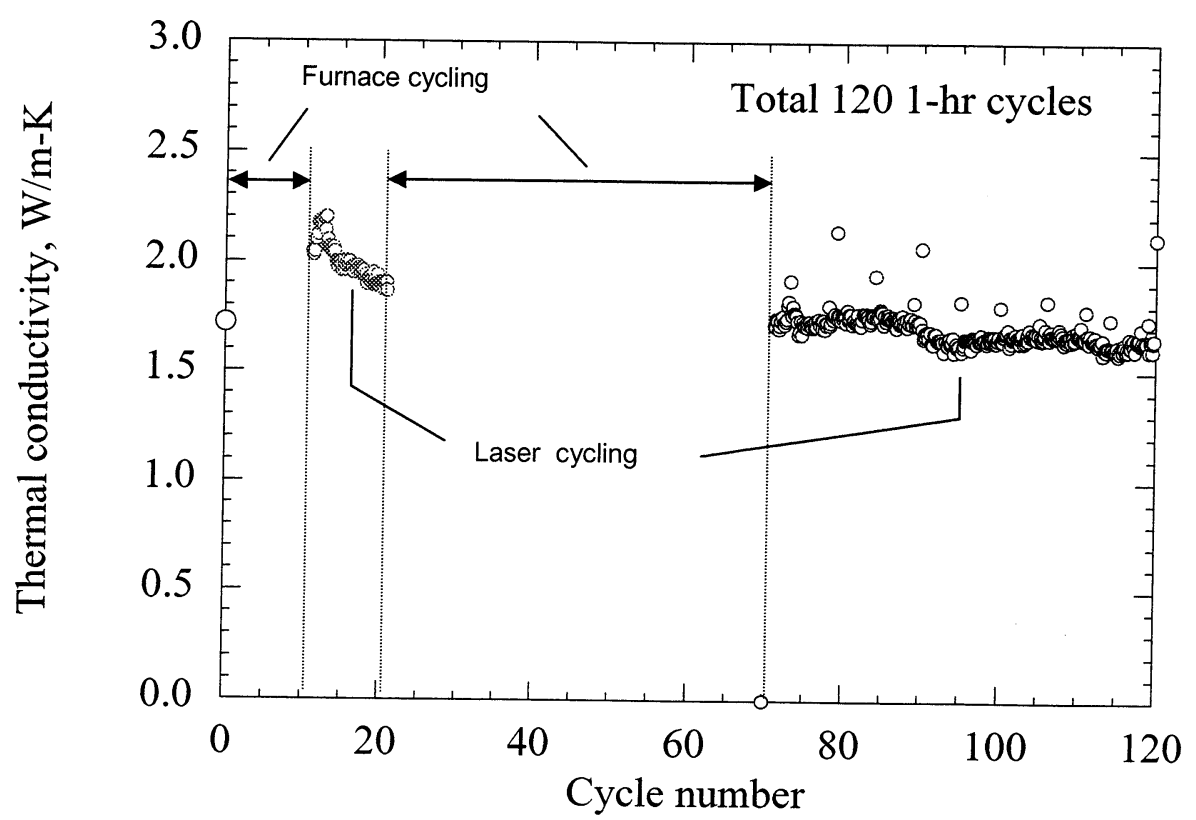

Fig. 18 Effect of extended thermal cycling on thermal conductivity of mullite+BSAS/BSAS on MI (combination of $1 \mathrm{~h}$ furnace cycles at $1300^{\circ} \mathrm{C}$ and $1 \mathrm{~h}$ laser cycles at $1482^{\circ} \mathrm{C} \mathrm{EBC}$ surface temperature and $1316^{\circ} \mathrm{C} \mathrm{EBC/MI}$ interface temperature)

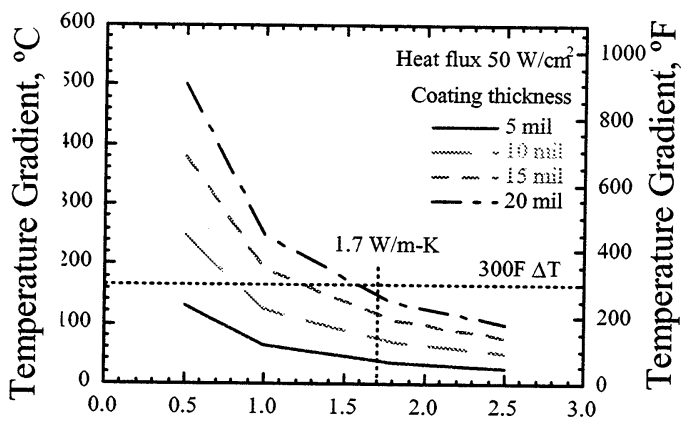

Thermal Conductivity, $\mathrm{W} / \mathrm{m}-\mathrm{K}$

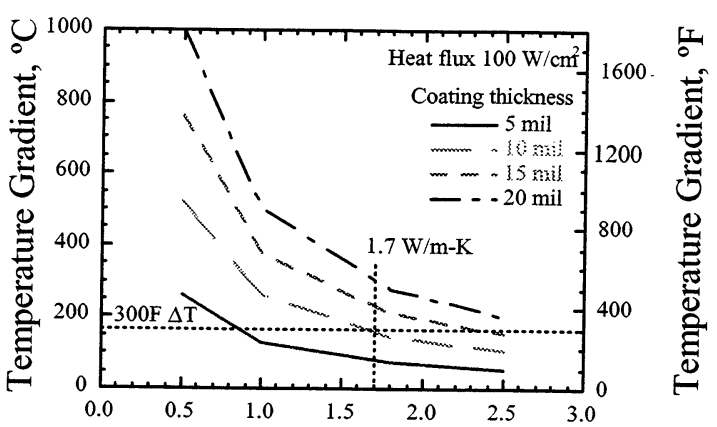

Thermal Conductivity, W/m-K

Fig. 19 The plot of EBC conductivity vs. temperature reduction across EBC for two heat flux conditions $\left(50 \mathrm{~W} / \mathrm{cm}^{2}\right.$ and $\left.100 \mathrm{~W} / \mathrm{cm}^{2}\right)$ 
Public reporting burden for this collection of information is estimated to average 1 hour per response, including the time for reviewing instructions, searching existing data sources, gathering and maintaining the data needed, and completing and reviewing the collection of information. Send comments regarding this burden estimate or any other aspect of this Davis Highway, Suite 1204, Arlington, VA 22202-4302, and to the Office of Management and Budg Serices, Dir Rerate for Information Operations and Reports, 1215 Jefferson

\begin{tabular}{|l|r} 
& $\begin{array}{r}\text { 2. REPORT DATE } \\
\text { March } 2002\end{array}$ \\
\hline 4. TITLE AND SUBTITLE & March
\end{tabular}

Technical Memorandum

\section{TITLE AND SUBTITLE}

Upper Temperature Limit of Environmental Barrier Coatings Based on Mullite and BSAS

6. AUTHOR(S)

$$
\text { WU-714-04-30-00 }
$$

K.N. Lee, D.S. Fox, J.I. Eldridge, D. Zhu, R.C. Robinson, N.P. Bansal, and R.A. Miller

\section{PERFORMING ORGANIZATION NAME(S) AND ADDRESS(ES)}

National Aeronautics and Space Administration

John H. Glenn Research Center at Lewis Field

Cleveland, Ohio 44135-3191

8. PERFORMING ORGANIZATION REPORT NUMBER

E-13195

\section{SPONSORING/MONITORING AGENCY NAME(S) AND ADDRESS(ES)}

National Aeronautics and Space Administration

Washington, DC 20546-0001

10. SPONSORING/MONITORING AGENCY REPORT NUMBER

NASA TM-2002-211372

\section{SUPPLEMENTARY NOTES}

K.N. Lee, Cleveland State University, Cleveland, Ohio; D.S. Fox, J.I. Eldridge, N.P. Bansal, and R.A. Miller, NASA Glenn Research Center; D. Zhu, Ohio Aerospace Institute, Brook Park, Ohio; R.C. Robinson, QSS Group, Inc., Cleveland, Ohio. Responsible person, K.N. Lee, organization code 5160, 216-433-5634.

12a. DISTRIBUTION/AVAILABILITY STATEMENT

Unclassified - Unlimited

Subject Categories: 24 and 27

Distribution: Nonstandard

Available electronically at http://gltrs.grc.nasa.gov/GLTRS

This publication is available from the NASA Center for AeroSpace Information, 301-621-0390.

13. ABSTRACT (Maximum 200 words)

Current state-of-the-art environmental barrier coatings (EBCs) for Si-based ceramics consist of three layers: a silicon bond coat, an intermediate mullite $\left(3 \mathrm{Al}_{2} \mathrm{O}_{3}-2 \mathrm{SiO}_{2}\right)$ or mullite $+\mathrm{BSAS}\left(1-\mathrm{xBaO}-\mathrm{xSrO}-\mathrm{Al}_{2} \mathrm{O}_{3}-2 \mathrm{SiO}_{2}\right)$ layer, and a BSAS top coat. Areas of concern for long-term durability are environmental durability, chemical compatibility, silica volatility, phase stability, and thermal conductivity. Variants of this family of EBCs were applied to monolithic SiC and melt infiltrated $\mathrm{SiC} / \mathrm{SiC}$ composites. Reaction between BSAS and silica results in low melting $\left(\sim 1300^{\circ} \mathrm{C}\right)$ glasses at $\mathrm{T}>1400^{\circ} \mathrm{C}$, which can cause the spallation of the EBC. At temperatures greater than $1400^{\circ} \mathrm{C}$, the BSAS top coat also degrades by formation of a porous structure, and it suffers significant recession via silica volatilization in water vaporcontaining atmospheres. All of these degradation mechanisms can be EBC life-limiting factors. BSAS undergoes a very sluggish phase transformation (hexagonal celsian to monoclinic celsian), the implications of which are not fully understood at this point. There was evidence of rapid sintering at temperatures as low as $1300^{\circ} \mathrm{C}$, as inferred from the sharp increase in thermal conductivity.

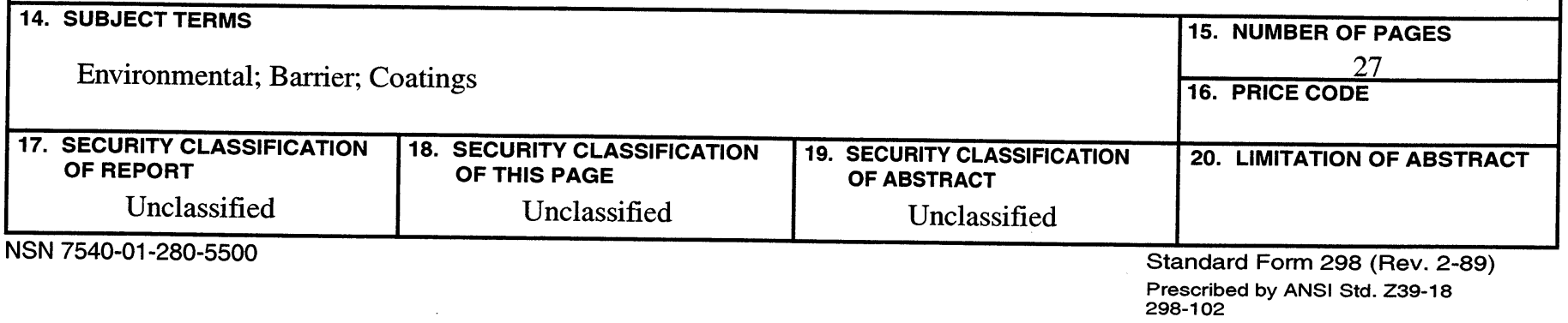

